\title{
RELATIONSHIP OF SOCIAL MEDIA AND PUBLIC POLICY FROM THE PERSPECTIVE OF SOCIAL MEDIA USERS: CASE OF UNIVERSITY STUDENTS
}

\author{
Mehmet Devrim Aydın*, Volkan Göçoğlu ** \\ * Hacettepe Üniversitesi, **Hacettepe Üniversitesi \\ E-mail: mehmetdevrim@gmail.com,volkangocoglu@gmail.com
}

Copyright (C) 2015 Mehmet Devrim Aydın, Volkan Göçoğlu. This is an open access article distributed under the Eurasian Academy of Sciences License, which permits unrestricted use, distribution, and reproduction in any medium, provided the original work is properly cited.

\begin{abstract}
In recent years, social media has gained a considerable power with an influence reaching public order and political agenda all over the world. The relationship between public policy and social media plays a significant role in social media's soaring importance. This study aims at examining the relationship between public policy and social media through social media users' perception. With this aim in mind, a field study was conducted with the participation of the most active user group of social media, university students, in order to assess their perception of the relationship between social media and public policy. In this framework, firstly, the study dwells on the relationship between public policy and social media within a conceptual framework. In the second part of the study, a survey was conducted with the participation of 104 undergraduate students who are studying in Hacettepe University, Political Science and Public Administration Department. Findings were discussed by comparing those of two important studies from Turkey and USA. In the conclusion section, results of the study were listed and some suggestions on improving public policy making process were made.
\end{abstract}

Keywords: Public Policy, Social Media, Public Policy Making, University Students.

\section{Sosyal Medya Kullanıcıları Perspektifinden Sosyal Medya-Kamu Politikası İlişkisi: Üniversite Öğrencileri Örneği}

\section{ÖZET}

Son y1llarda sosyal medya, dünyanın her bölgesinde kamu düzenini ve siyasal gündemi etkileyecek derecede yüksek bir güce ulaşmıştır. Sosyal medyanın söz konusu güce ulaşmasında, bu oluşumun kamu politikaları ile olan ilişkisi önemli rol oynamaktadır. $\mathrm{Bu}$ çalışma, kamu politikası ve sosyal medya arasındaki ilişkiyi sosyal medya kullanıcılarının algıları üzerinden incelemeyi amaçlamaktadır. Bu amaçla, sosyal medyayı en yoğun kullanan kesim olan üniversite öğrencilerine odaklanılmış ve onların sosyal medya ve kamu politikası arasındaki ilişkiyi nasıl algıladıkları bir alan araştırması ile incelenmiştir. $\mathrm{Bu}$ çerçevede, çalışmada öncelikle, kamu politikası ve sosyal medya ilişkisi çeşitli kavramlar açısından ele alınmıştır. Alan araştırması kısmında ise, Hacettepe Üniversitesi Siyaset Bilimi ve Kamu Yönetimi Bölümünde lisans düzeyinde öğrenim görmekte olan 104 öğrenciye anket uygulanmıştır. Elde edilen bulgular, biri Türkiye'den diğeri ise ABD'den olmak üzere iki önemli çalışmanın bulgularıyla karşılaştırılarak tartışılmıştır. Sonuç bölümünde ise araştırma 
sonuçları sıralanmış ve kamu politikası üretim sürecini iyileştirecek bazı önerilere yer verilmiştir.

Anahtar Kelimeler: Kamu Politikası, Sosyal Medya, Kamu Politikası Üretimi, Üniversite Öğrencileri

\section{Giriş}

Sosyal medya, içinde bulunulan zaman diliminde en önemli iletişim ve haberleşme araçlarından biri haline gelmiştir. Kamu politikasının üretilmesi, uygulanması ve sonuçlarının değerlendirilmesinde üniversite gençliğinin bu süreçlere katılımı konusunda sosyal medya, önemli görevler üstlenmektedir.

Sosyal medyanın kamu politikası ile ilişkisi farklı yönlerden ele alınabilmektedir. Sosyal medya oluşumunun, üretilen kamu politikasına etki etmesi bu ilişskinin boyutlarından biridir. Kamu politikasını üreten devlet organlarının sosyal medya kullanımı ve kendi kurumlarına özgü sosyal medya politikaları üretmeleri de bağlantılı başka bir boyuttur. Sosyal medya aracıllığıyla oluşturulan kamuoyu, kamuoyu baskısı ve sosyal medyanın sonuçlarından biri haline dönüşebilen dezenformasyon kavramları da bu ilişki içerisinde yer alan diğer önemli konulardır.

İnsanların öncelikle kendi özel hayatları için kullanmaya başladıkları sosyal medya, daha sonra arkadaş ve aile ilişkilerinde de kullanılan bir iletişim aracı haline gelmiştir. Son yıllarda iş hayatındaki ilişkilerde önemli bir yer tutmaya başlayan bu oluşum, devlet organları ile bireyler arasındaki ilişkileri içeren resmi hayatta da yer bulmuştur (Hrdinovâ vd., 2010: 3). Devlet organlarının, dolayısıyla kamu politikası üreticilerinin bu oluşumu kullanması başlı başına, kamu politikası ve sosyal medya ilişkisinin temelini oluşturmaktadır.

Bu çalışma, "Kamu Politikası ve Sosyal Medya İlişkisis" gibi son derece yeni bir alanda Türkiye'deki ilk çalışmalardan biri olarak, ilerideki muhtemel çalışmalara da önemli bir katkı sağlamak üzere kamu politikası ve sosyal medya arasındaki ilişkiyi üniversite gençliği algısı boyutunda incelemeyi amaçlamaktadır. Söz konusu algının belirlenmesi için bir alan araştırması gerçekleştirilmiştir. Bu kapsamda çalışma, iki bölümden oluşmaktadır. Birinci bölümde, sosyal medya öncelikle kamu politikasını etkileyen bir unsur olarak ele alınmıştır. Akabinde, Türkiye'de devlet kurumlarınca üretilen sosyal medya politikaları ve meclisteki dört siyasi partinin sosyal medya kullanımları incelenmiştir. Çalışmanın alan araştırmasını oluşturan ikinci bölümünde ise; araştırma grubunu seçim aşamasında, sosyal medya kullanım sıklığı en yüksek grubu oluşturmaları nedeniyle üniversite öğrencilerine yönelinmiş ve kamu politikası konusunda daha yüksek bilince sahip olduğu düşünülen Siyaset Bilimi ve Kamu Yönetimi bölümü lisans öğrencilerine odaklanılmıştır. Bu çerçevede, Hacettepe Üniversitesi, Siyaset Bilimi ve Kamu Yönetimi bölümü lisans öğrencilerine "Kamu Politikası ve Sosyal Medya İlişkisi” başlıklı bir anket uygulanmıştır. Çalışmanın tartışmalar başlığı altında, anket sorularının bazılarının alındığı, Amerika Birleşik Devletleri'nde ve Türkiye'de yapılmış benzer iki araştırmanın bulguları, bu alan araştırmasının bulgularıyla karşılaştırılarak tartışılmıştır. Bulgular yorumlanırken, kamu politikası ve sosyal medya kavramları arasındaki ilişki, anketlere katılan farklı katılımcılar temelinde incelenerek sonuçlar daha geniş demografik özellikler çerçevesinde ve farklı değişkenler göz önünde bulundurularak karşılaştırılmıştır.

\section{KAMU POLITIKASI VE SOSYAL MEDYA ILIŞKISINIIN SIYYASAL YAŞAM BAKIMINDAN İNCELENMESI}

Çalışmanın bu bölümünde kamu politikası ve sosyal medya, siyasal yaşam sınırları içerisinde incelenmektedir. Bu bağlamda, kamu politikalarına etkide bulunan bir unsur olarak sosyal medya, devletin sosyal medyaya verdiği önemi görebilmek adına; devlet kurumlarınca 
oluşturulan sosyal medya politikaları ve son olarak da siyasi partilerin sosyal medyaya verdikleri önemi görebilmek adına da siyasi partilerin sosyal medya kullanımları incelenecektir. Söz konusu yönde yapılacak incelemeyle birlikte alan araştırmasında elde edilecek bulgular ve sonuçların teorik ve pratik çerçevesine zemin hazırlanmaya çalışılmıştır. Ayrıca araştırmada (sorular, yorumlar ve tartışmada) geçecek olan terimlere değinilmektedir.

\subsection{Kamu Politikasını Etkileyen Bir Unsur Olarak Sosyal Medya}

Dünya genelinde çok sayıda hükümet, kamu politikası açısından sosyal medyanın önemini kabul etmiştir. $\mathrm{Bu}$ farkındalık doğrultusunda hükümetler, yönetimlerinde bulunan devlet organlarında sosyal medya kullanımını artırmaya çabalamaktadır. Lee ve arkadaşlarının (2013) belirttiği üzere ABD'den Birleşik Arap Emirliklerine ve Avustralya'ya kadar birçok hükümet, vatandaşlarla "gerçek zamanlı" ve "esnek" etkileşim kurabilmeleri için devlet organlarının sosyal medya kullanımlarını desteklemektedir.

Modern demokrasilerde, politikacılara doğrudan etkide bulunan unsur vatandaşlardır. Sosyal medyanın yaygınlaşması, hem vatandaşlar hem de politikacılar tarafından kullanılması, bu ikisi arasındaki etkileşimi hızlandırmıştır. Hızlanan bu etkileşim, halkın uygulamalara tepkisinin politikacılara ulaşma ve politikacıların yaptıkları uygulamalardan dolayı halka hesap verme süresini de kısaltmıştır (Çildan vd., 2012). Sosyal medya sayesinde vatandaşlar, kurumların ilgili birimlerine telefon, dilekçe ya da mektup ile ulaşmak yerine sosyal medya platformları aracılığıyla (örnek: Twtitter) kurumların başındaki politikacılara diğer vatandaşların da görebileceği bir platformda "tweet" gönderebilmektedir (McNutt, 2012: 13). Üniversite öğrencileri de oy kullanma hakkına sahip olmaları, genç nüfusun önemli bir kısmını oluşturmaları ve kamu politikalarına etki güçlerinin yüksek olmalarıyla birlikte aynı zamanda birer ülke vatandaşıdır.

Sosyal medyanın kamu politikasını etkilemesinde, kamu politika üreticilerinin sosyal medyadan gelen bilgileri ne denli dikkate aldığı önemlidir. Leavey (2013) yaptığı çalışmada, vatandaşların talepleri ve tepkileri hakkında sosyal platformlardan edinilecek bilginin önemini vurgulamaktadır. Çalışmada, elde edilecek bilgilerin kullanımında meydana gelecek fırsatları ve riskleri de irdelemiştir. Leavey (2013), sosyal medyada bireylere ilişkin bilgilerin güvenliği ve güvenilirliği konusunda riskler olduğunu savunmaktadır. Öte yandan, çok sayıda bilgiye kolay ve hızlı bir şekilde ulaşma avantajı nedeniyle, kamu politikası üreticilerinin, politika üretim sürecinde sosyal platformların sunduğu yararları da vurgulamıştır.

Sosyal medyanın kamu politikasına etki oranını yükselten bir diğer faktör Sivil Toplum Kuruluşlarıdır (STK). STK'ların kitleleri bir araya getirmek üzere sosyal medyayı kullanmasının yanında, sosyal medya platformlarında oluşan gayri resmi STK'lar da mevcuttur. C1lızoğlu ve Karagöz (2007: 13), STK'ların, iletişimin iki boyutundan yararlanarak toplumsal dönüşüm ve değişime etki ve aracılık edeceğini vurgulamışlardır. Yazarlara göre, bu boyutlardan birincisi; STK'ların bir örgüt olarak örgütsel iletişim sistemlerinden yararlanması boyutudur. Sosyal medya da STK'ların örgüt içi iletişiminde önemli rol oynayan iletişim araçlarından biri haline gelmiştir. İkinci boyut ise örgütlerin dışarı ile iletişim kurdukları normal iletişimin işlevlerini kapsayan boyuttur. Söz konusu boyut ile sosyal medya ilişkisi kurulduğunda STK'lar, ilgili oldukları olay ya da konuyu örgüt dışı bireylere ulaştırabilmektedirler.

Akbıyık ve Öztürk'ün (2012: 1013) belirttiği üzere, bir STK kurmak resmi prosedürler ve maddi giderler dolayısıyla zor ve zahmetli bir iştir. Sosyal medya platformları üzerinden bir konu ya da olay çevresinde insanları bir araya getirmek ise çok daha hızlı, kolay ve ücretsizdir. Gençlerin sosyal medyaya olan yatkınlıkları ve özellikle üniversitelilerin çeşitli konu ve olaylara karşı bu platformlarda bir araya gelerek örgütlenmeleri de bahsedilen bu oluşumlara örnektir. 
Esen'in (2013), çalışmasında vurguladığı üzere sosyal medya ve gençlik arasındaki bağlantı önemli boyutlara ulaşmıştır. Gençlik hareketlerinin özellikle Türkiye tarihinde önemli etkiler bırakmış olması, sosyal medyanın bu gençlik hareketleri üzerindeki hızlandırıcı ve kolaylaştırıcı etkisinin önemini de artırmıştır.

İnternet teknolojilerinin gelişimi ile birlikte ele alınması gereken bir diğer konu da küreselleşmedir. Küreselleşme ile birlikte ulus devletlerin önemi azalmıştır. Çalışmanın odak olarak aldığı kamu politikası, daha genel olarak ulusal boyutta etkili olacak politikalar olsa da, bu kamu politikasına sosyal medyadan gelecek etki uluslararası bir boyutta olabilmektedir.

Bir devlet içerisinde üretilen kamu politikası (Türkiye'den örnek olarak; internet yasası) ${ }^{1}$ vatandaşlarca sakıncalı görülüp tepki doğurabilmektedir. Küresel anlamda başka ülkelerden bu tepkileri haklı bulan diğer insanlar da sosyal medya üzerinden bu tepkilere katılarak,

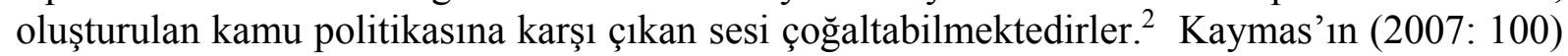
belirttiği üzere; geleneksel medya ve yeni medya teknolojileri arasındaki sınırlar artık iç içe geçmiş bir durumdadır. Bu durumun oluşmasında iletişim ve haberleşmede sosyal medya kullanımının yaygınlık kazanması rol oynamıştır. Kamu politikasının duyurulması, vatandaşlara haber verilmesi, vatandaş tepkilerinin gündeme getirilmesinde radyo ve televizyon gibi geleneksel medya araçlarının önemli bir rol oynadığı yok sayılamaz bir gerçektir. Gelişen internet ve mobil teknolojilerin beraberinde büyüyen sosyal medya oluşumunun da artık bu görevi paylaştı̆̆ını söylemek yanlış olmayacaktır. Bu çerçevede New York Times'ın bir sosyal medya editörü kiralaması (Nolan, 2009'dan akt. Kietzmann vd., 2011: 241) ve Katolik Kilisesi'nde kilisenin sosyal medyayı nasıl kullanabileceğine dair internet seminerleri verilmesi (Kietzmann vd., 2011: 241) bunun açık göstergesidir. Kilisenin de dolaylı olarak kamu politikası oluşturan ve oluşturulan kamu politikasını etkileyen bir unsur olduğu göz ardı edilmemelidir.

Küreselleşme sürecinin ürünlerinden biri olan "yönetişim” kavramı, ülke yönetiminde yalnızca iktidarın olmaması gerektiğini, STK'lar ve özel sektörün de bu yönetim ve karar süreçlerinde yer alması gerektiğini savunmaktadır (Özer, 2006: 68). Puppis'in (2010: 138) "medya sistemlerini bütüncül olarak organize etmeyi amaçlayan yapısal bir düzenleme" olarak tanımladığı "medya yönetişimi" içerisinde sosyal medya da yer alacaktır. Önerilen böyle bir yapıda ya da dışında sosyal medya, genel "yönetişim" kavramı içerisinde hızlandırıcı ve kolaylaştırıcı bir rol oynamakta ve devletin hesap verebilirliği, politikaların açık ve şeffaf bir şekilde yürütülebilmesi açısından önem arz etmektedir.

Literatür incelemelerinden ve yapılan yorumlardan anlaşıldığı üzere; sosyal medya hızlı ve kolay bir iletişim sağlamasıyla kamu politikasını etkilemektedir. Bu etki, iletişim fonksiyonuna bağlı olarak gelişen bir etki olmasına karşın farklı şekillerde yön bulmaktadır. Sosyal medyayı kullanan kamu politikası üreticileri, sosyal medyadan aldıkları verileri politika üretim sürecinde kullanabilmekte ve böylece tepkileri önceden kestirerek politikaya yön verebilmektedirler. Politika uygulama sürecinde ya da sonrasında oluşan tepkileri de bu oluşum sayesinde takip edebilirler. Sosyal medya kullanan üniversite öğrencileri ise, sosyal platformlarında kolaylıkla diğerleriyle iletişim kurabilmekte ve tepki gösterdikleri konulara karşı yandaş bulabilmektedirler. Bunun yanında öğrenciler, sosyal medya kullanımının devlet organları ve

\footnotetext{
1Türkiye' de 2014 yılı Şubat ve Mart aylarında devam eden “Yeni İnternet Yasası” ile ilgili söylemler hakkında örnek bir haber için http://www.haberler.com/yeni-internet-yasasi-onaylandi-iste-10-maddede-5685863-haberi/ internet sitesine göz atılabilir. Erişim Tarihi: 12.03.2014.

2Türkiye' de Cumhurbaşkanı Abdullah Gül tarafından imzalanan İnternet Yasası'nın yurt dışı kaynaklı bir kişisel internet haber sitesinde yer aldığı ve bu haberin altında sosyal medya platformlarından Türk vatandaşı olmayan bireylerin de tepkide bulunduğu gözlemlenebilmektedir. Bkz. http://www.juancole.com/2014/02/thousands-president-censorship.html Erişim Tarihi: 13.03.2014.
} 
politikacılarca artması dolayısıyla onlarla direk iletişimde bulunma ve kamu politikasına etki etme şansina sahiptirler. Kitlelerin bir araya gelerek büyümesine ve güçlenmesine doğrudan etkide bulunan sosyal medya, sadece kamu politikasını etkileyen değil, aynı zamanda iktidarları yıkabilen bir güç haline gelmiştir.

\subsection{Devlet Kurumlarınca Üretilen Sosyal Medya Politikaları}

Sosyal medyanın gelişmesine bağlı olarak devlet organları ve hatta devlet çalışanları bu oluşumun içinde yer almaya başlamıştır. Devlet organlarının sosyal medya kullanım oranları ülkeden ülkeye değişmektedir. Kullanım durumlarına göre bu organların kurumsal ya da ulusal boyutta belirlenmiş bir sosyal medya politikaları olabilmektedir.

Kanada'nın bir eyaleti olan Alberta'da belirlenmiş bir Sosyal Medya/Web 2.0 politikası vardır. $\mathrm{Bu}$ politika, yönetim tarafından yazılı olarak yayınlanmıştır. ${ }^{3}$ Yayınlanan bu yazıda devlet organlarının hangi sosyal platformlarda temsil edileceği, kurumsal ve bireysel sosyal medya hesaplarının nasıl kullanılacağı konusunda bilgiler verilmiştir. Kurumsal ve özel hayat ayrımına dayanarak, kamu çalışanının bu ikili ayrımdaki sosyal medya kullanımında nelere dikkat etmesi gerektiği vurgulanmıştır.

Avustralya'da 2009 yılı Kasım ayında Kamu Hizmeti Komisyonu tarafından kamu çalışanları için daha güçlü bir karar alma ve uygulama süreci geliştirilmesine imkan sağlaması öngörülen Web 2.0 (sosyal medya) kullanım kılavuzları çıkarılmıştır (Fyfe ve Crookall, 2010: 37). İngiltere ise sosyal medya politikaları konusunda daha organize olmuş bir izlenim vermektedir. İngiltere Merkezi Bilgi Ofisi, kamu çalışanlarının sivil hayatta sosyal medya kullanımlarına yön vermek amacıyla 2009 Mart ayında 12 sayfalık bir kılavuz yayınlamıştır (Fyfe ve Crookall, 2010: 44).

Devletlerin belirledikleri sosyal medya politikaları sadece yol gösterici olmakla kalmayıp, bağlayıcı kurallar da olabilmektedir. Jacobson ve Tufts'ın (2013) devletlerin sosyal medya politikaları temelinde kamu çalışanlarının haklarını irdeleyen çalışmalarında, ABD'de yer alan ve sosyal medya politikasına sahip olan eyaletler sıralanmıştır. Sosyal medya politikasının bağlayıcılığı konusunda burada sıralanan Vermont eyaletinin Milton kasabasının sahip olduğu sosyal medya politikası, ilgili konuya örnek gösterilebilir. ${ }^{4}$ Bu kasabanın resmi organlarından herhangi birinde çalışacak olan bireyin imzalaması gereken bu belge, devlet yönetimi tarafından uygulanan sıkı bir sosyal medya politikasının ürünüdür.

Devlet organlarınca uygulanan sosyal medya politikalarına Türkiye açısından bakıldığında durum pek iç açıcı gözükmemektedir. Kuzma'nın (2010: 8) Google'da ülke ismi, "government" ve "social media web site" anahtar sözcüklerini yan yana kullanarak yaptığı aramada Türkiye için resmi bir hükümet sosyal medya sitesi bulunamamıştır. Araştırma 2010 yılında yapılmasına rağmen, aynı anahtar sözcükler kullanılarak 14.03.2014 tarihinde yapılan aramada da bir sonuç

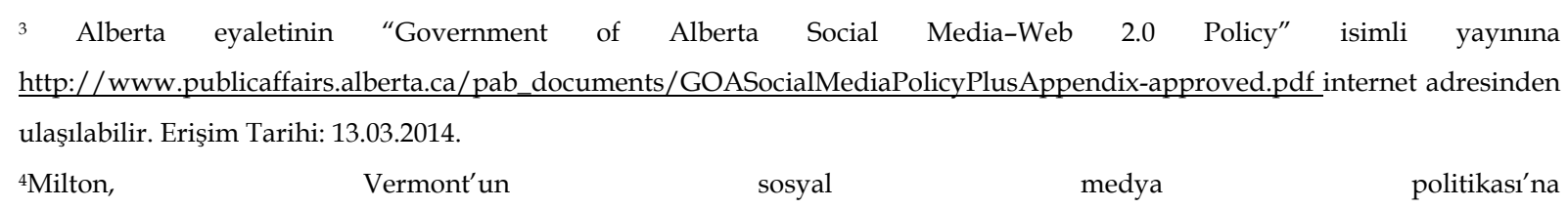
http://www.miltonvt.org/images/pdffiles/government/docs/SocialMediaPolicy.pdf internet adresinden ulaş1labilmektedir. Erişim Tarihi: 13.03.2014.

Buradaki dosyanın sonuna gelindiğinde dikkat çekeceği üzere; çalışandan belgede sıralanan tüm şartlarını kabul ettiğini beyan eden bir imza istenmektedir.

Bunun dışında bağlayıcı sosyal medya politikaları sadece resmi kurumlarda değil, özel sektör kurumlarında da uygulanmaktadır. Buna örnek olarak ise Rockwood şirketinin Türkçeye'de çevrilmiş sosyal medya politikasının tamamı için şu internet adresine göz atılabilir; http://www.rockwoodspecialties.com/policies/pdf/turkish/Rockwood_Social_Media_Policy_TR.pdf 
bulunamamıştır. Bu sonuç, Türkiye'nin devlet organları boyutunda bir sosyal medya politikasının olmamasının göstergelerinden biridir.

Türkiye'de devlet organlarınca oluşturulmuş sosyal medya politikaları bulunmamaktadır. ${ }^{5}$ Ülkedeki politikacıların, devlet kurumlarının ve yerel yönetim kuruluşlarının sosyal medya kullanımları gün geçtikçe artıyor olsa da, ${ }^{6}$ bu kullanımı düzenlemeye yönelik sosyal medya politikaları hayata geçirilmemektedir. Kuruluş kanunu ve geçmişten bugüne gelen yapısıyla devlet ile ilişkili olan tek bir örnek olarak verilebilecek Anadolu Ajansı (AA) bir sosyal medya politikasına sahiptir. Kurumun resmi internet sitesinin "kurumsal" bölümünde yer alan sosyal medya politikasında, kurum çalışanlarının sosyal medya kullanımlarında önem vermeleri gereken davranışlar sıralanmaktadır. ${ }^{7}$

Konu yerel yönetimler açısından ele alındığında, Türkiye'de belediyelerin kendilerine ait birer sosyal medya politikalarının olup olmadığının saptanması, belediye sayısının fazlalığından ve bu belediyelerin kendi aralarındaki gelişmişlik farklılıklarından dolayı çok zordur. Yapılan Google aramasında, ${ }^{8}$ internet üzerinde yazılı bir sosyal medya politikasına sahip olan belediyeye rastlanmamıştır. Buna rağmen, bir genelleme yaparak, Türkiye'deki yerel yönetimlerin belirli sosyal medya politikalarına sahip olmadıklarını iddia etmek doğru olmayacaktır. İnternet üzerinde sosyal medya politikasını yayınlamayan ancak, çalışanlarına sözlü ya da yazılı sosyal medya politikası uygulayan belediyelerin var olabileceği göz önüne alınmalıdır. Bu başlık altında ele alınan ve merkezi yönetimin organlarından olan devlet kurumlarında ise durum farklı olup; belirli sayıda olan bu kurumların resmi internet siteleri ayrıntılı olarak incelenmiştir.

Sosyal medya kullanımı günümüzde temel iletişim ve haberleşme araçlarından biri haline gelen bir oluşumdur. Sosyal medya oluşumunun insan ve toplum hayatında geldiği önemli nokta, devlet yöneticileri tarafından da kabul edilmiş gözükmektedir. Devlet organlarında çalışan bireylerin de bu oluşumun birer kullanıcısı olduğu gerçeği göz ardı edilmemelidir. Yapılan literatür incelemesi sonucunda görüldüğü üzere devlet organları bu gerçeğe paralel olarak, kendilerine sosyal medya politikaları oluşturmaktadır. Türkiye'de bu durumun önemi henüz kavranmamış olsa da, sosyal medyanın gün geçtikçe yaygınlaşan kullanımı sonucunda, kamu kurumlarının bu tür politikalara yöneleceği düşünülmektedir.

\subsection{Türkiye'de Siyasi Partilerin Sosyal Medya Kullanımları}

İletişim ve haberleşme sosyal medyanın temel fonksiyonudur. Siyasi partilerin sosyal medyayı kullanma eğilimleri de onun halk ile olan iletişimdeki faydalarından kaynaklanmaktadır.

Sosyal medyanın eş zamanlı, kolay bulunabilen ve ulaşılabilir (Landau, 2011: 19) olması, iletişim konusunda büyük ölçüde tercih edilmesinin nedenlerindendir. Sosyal medya

\footnotetext{
${ }^{5}$ Kuzma' nın (2010) yaptığı araştırmaya paralel olarak Google' da, hizmet alanları gereği öncelikli olarak sosyal medya hesaplarına sahip olması beklenebilecek Ulaştırma, Denizcilik ve Haberleşme Bakanlığı, Bilim, Sanayi ve Ticaret Bakanlığı, Aile ve Sosyal Politikalar Bakanlıkları'nın internet sitelerinde yer alan "Hakkında", "Hizmetlerimiz" ve "Mevzuat" bölümleri taranmış ancak bir sosyal medya politikası bulunamamıştır. Yerel yönetim kuruluşlarını taramak amacıyla yine google'da İstanbul, Ankara ve İzmir olmak üzere temsili üç büyük şehirin isimleri ve ardından “belediyesi sosyal medya politikası” anahtar sözcükleri girilerek tarama yapılmış ve bir sonuca ulaşılamamıştır. Erişim Tarihi: 14.03.2014.

${ }^{6}$ Devlet kurumlarının sosyal medya kullanımlarına yönelik Papilion Digital'in araştırmasına http:// sosyalmedya.co/bakanliklarsosyal-medya-analizi/ internet adresinden ulaşılabilir. Erişim Tarihi: 14.03.2014.

${ }^{7} \mathrm{AA}^{\prime} \mathrm{n}$ n sosyal medya politikasına http://www.aa.com.tr/tr/kurumsal/52571--sosyal-medya-politikalari adresinden ulaşılabilir. Erişim Tarihi: 14.03.2014.

${ }^{8}$ Arama Haziran 2014'te Google arama motoruna; "belediye sosyal medya politikası", "sosyal medya belediye" anahtar kelimeleriyle yapılmış olup herhangi bir sonuca ulaşılamamıştır.
} 
platformlarında yer alan kullanıcılar, takipçileri ya da arkadaşları olarak kendilerine bağlı bulunan diğer kullanıcılara her an ulaşabilmektedir. Sürekli yanlarında taşıyabildikleri mobil cihazları sayesinde neredeyse her yerden internete bağlanabilmektedirler. Buna bağlı olarak sosyal medya platformları sayesinde daha önceden çoğunlukla "iki kişi arasında" olan bireysel iletişim ve haberleşme şekli, daha kitlesel boyutlara taşınmıştır (IBM, 2008).

Sosyal medya, habercilik alanında alışılagelmiş basın ve yayın organlarının önüne geçmektedir. Özellikle yakın dönemde vuku bulan Taksim Gezi Parkı ve Occupy Wall Street (Wall Street'i İşgal Et) olaylarında, olayların geçtiği yerlerde bulunan sosyal medya kullanıcılarınca olay yerinde ve anında aktarılan resimler ve videolar, insanlara televizyon kanallarından önce ulaştırılmıştır. Birçok televizyon kanalları ve gazeteler sosyal medya kullanıcılarından edinilen bu görselleri yayınlamışlardır. ${ }^{9}$

Türkiye'nin tanık olduğu Gezi Parkı olayları sırasında, sosyal medya üzerinde görsel ve işitsel yayınlar dışında yazılı olarak da Twitter üzerinden iletişim ve haberleşme sağlanmıştır. Türkiye'de günlük ortalama 8-10 milyon adet olan atılan tweet sayısı, olayların başladığ tarih 31 Mayıs 2013 'te 15 milyon, 1 Haziran 2013'te ise 27 milyon adete ulaşmıştır (Kesen, 2013: 20).

Politika ve siyasette sosyal medya kullanımının dünya genelinde politikacılar tarafından ilk olarak Barack Obama ve John Edwards ile popülerliğe ulaştığı (Mischand 2007'den akt. Jackson ve Lilleker, 2011: 88) çalışmada daha önceden belirtilmiştir. Mercek altına alınan bölgeyi biraz daha küçülterek politika ve siyasette sosyal medya kullanımını Türkiye'deki siyasi partiler çerçevesinden incelemenin temsil bakımından yeterli sonucu vereceği düşüncesi yanlış olmayacaktır. Bu bağlamda Türkiye Büyük Millet Meclisi'nde (TBMM) bulunan partilerin resmi internet siteleri üzerinden yapılacak kısa bir inceleme, siyasi partilerin sosyal medya kullanımı hakkında aydınlatıcı olacaktır. Sözü edilen inceleme yapılırken; siyasi partilerin resmi internet sitelerinin ana sayfalarında sosyal medya hesaplarının mevcut olup olmadığı saptanacak, mevcut olan hesapların gönderi sıklıkları belirlenecektir.

Türkiye'de iktidarda bulunan Adalet ve Kalkınma Partisi (AKP) resmi internet sitesinde, ${ }^{10}$ partiye ait Facebook ve Twitter hesapları bulunmaktadır. ${ }^{11}$ Partiye ait kurumsal Twitter profilinde, paylaşılmış 2.307 Tweet gönderisi bulunmaktadır. Bu gönderilerin sonuncusu sayfa erişim tarihinden bir gün önce paylaşılmıştır. Partinin kurumsal Facebook profilinde ise incelemenin yapıldı̆̆ gün ve önceki günler partinin etkinliklerinde çekilen fotoğraflar paylaşılmıştır. Anlaşılacağı üzere, Ak Parti'nin sosyal medya kullanımı aktif bir şekilde sürmektedir.

TBMM'de milletvekili sayısı bakımından 2. Büyük parti olan Cumhuriyet Halk Partisi'nin (CHP), resmi internet sitesinde, ${ }^{12}$ Ak Parti'de olduğu gibi partiye ait Facebook ve Twitter hesapları bulunmaktadır. ${ }^{13}$ Ancak bu hesaplar parti adına değil, parti genel başkanı Kemal

\footnotetext{
${ }^{9}$ Gezi parkı olaylarının sosyal medya aracılığıyla yayılmış, televizyon kanalları ve gazetelerde yer almıs sosyal medya kullanıcılarınca kaydedilen görsel arşivlerine http://scriptogr.am/geziparkarsiv internet sitesi adresinden ulaşılabilir. Erişim Tarihi: 08.02.2014.

${ }^{10}$ AKP resmi internet sitesi: http://www.akparti.org.tr, Erişim Tarihi: 05.02.2014.

${ }^{11}$ Sözü edilen sosyal medya hesapları 05.02.2014 tarihinde parti resmi internet sitesinde sağ blokta görüntülenmiştir. Partinin kurumsal Twitter profilinin internet adresi: http://twitter.com/akparti, Facebook profilinin adresi: http://www.facebook.com/akparti olarak belirlenmiştir.

${ }^{12} \mathrm{CHP}$ resmi internet sitesi: http://www.chp.org.tr, Erişim Tarihi: 05.02.2014.

13Sözü edilen sosyal medya hesapları 05.02.2014 tarihinde parti resmi internet sitesinde sağ blokta görüntülenmiştir. Partinin kurumsal Twitter profilinin internet adresi: http://twitter.com/kilicdarogluk, Facebook profilinin adresi ise: http://www.facebook.com/K.Kilicdaroglu olarak belirlenmiştir.
} 
Kılıçdaroğlu adına açılmıştır. Kurumsal bir görünüm olmasa da, parti resmi internet sitesinde yayınlandığı için hesaplar kurumsal olarak varsayılacaktır. Partinin kurumsal Facebook profilindeki son gönderi, incelemenin yapıldığı tarihten yaklaşık 6 gün önce 31.01.2014 tarihinde paylaşılmıştır. Twitter profilindeki son gönderi ise aynı gün içinde paylaşılmıştır. Ele alınan ikinci parti CHP'nin de sosyal medya kullanımında aktif olduğu söylenebilmektedir.

Milliyetçi Hareket Partisi'nin (MHP) resmi internet sitesinde ${ }^{14}$ yukarıda ele alınan iki partide olduğu üzere partiye ait kurumsal Facebook ve Twitter hesapları yer almaktadır. ${ }^{15}$ Facebook hesabı parti adına, Twitter hesabı ise parti genel başkanı Devlet Bahçeli adına açılmıştır. Bahçeli adına açılan Twitter profilindeki son gönderi, incelemenin yapıldığı tarihten yaklaşık 24 gün önce gönderilmesine rağmen Facebook profilindeki son gönderi aynı gün, aynı saat içerisinde paylaşılmıştır. TBMM'nin üçüncü büyük partisi MHP'nin sosyal medya kullanımı için de yapılacak yorum CHP kadar aktif olduğu yönündedir.

Mukayeseli incelemenin yapıldığı tarih olan Şubat 2014'te, TBMM'de bulunan dördüncü büyük siyasi parti olan Barış ve Demokrasi Partisi'nin (BDP) milletvekilleri Haziran 2014'te Halkların Demokratik Partisi'ne (HDP) katılmıştır. Dolayısıyla, incelenen yapı eski adıyla artık mevcut değildir. O tarihteki adıyla BDP'nin www.bdp.org.tr adını taşıyan resmi internet sitesinde ${ }^{16}$ partiye ait Twitter, Facebook, Instagram, Youtube, Flickr, Tumblr, LinkedIn ve Ustream sosyal medya hesapları yer almaktadır. ${ }^{17}$ Sunulan sosyal medya hesaplarından Twitter ve Facebook profillerindeki son gönderiler incelemenin yapıldığı gün ve saat içinde gönderilmiştir. Youtube hesabına ise henüz video yüklenmemiştir. Instagram hesabında sadece bir paylaşım bulunmaktadır. Flickr profilinde paylaşılan iki fotoğraf gözlemlenmiş ve başka bir etkinlik bulunmamıştır. Tumblr hesabı sadece, partinin Facebook, Twitter ve Youtube sosyal medya hesaplarının reklamının yapıldığ 1 bir platform olarak kullanılmaktadır. LinkedIn hesabına ulaşılamamıştır. Ustream hesabı ise BDP seçim çalışmalarından canlı yayınlar yapan bir platform olarak aktif bir şekilde kullanılmıştır. Genel olarak değerlendirildiğinde, popüler sosyal medya platformlarının tamamına yakınında etkin ya da pasif bir şekilde de yer almasıyla BDP, sosyal medya kullanımı bakımından TBMM'deki en aktif siyasi parti olarak belirlenmiştir.

2015 yılında yapılan güncel taramada ${ }^{18}$ ulaşılan sonuçlara göre Ak Parti’nin Facebook, Twitter ve Youtube hesaplarına; CHP'nin Facebook, Twitter, Youtube ve Flickr hesaplarına; MHP'nin Facebook ve Twitter hesaplarına; son olarak HDP'nin ise Facebook, Twitter ve Youtube hesaplarına sahip olduğu gözlemlenmiştir. Tarama yapılan tarihin 7 Haziran 2015 genel

\footnotetext{
${ }^{14}$ MHP resmi internet sitesi: http://www.mhp.org.tr/mhp_index.php, Erişim Tarihi: 05.02.2012.

${ }^{15}$ Sözü edilen sosyal medya hesapları 05.02.2014 tarihinde parti resmi internet sitesinde să̆ üst blokta görüntülenmiştir. Partinin kurumsal Twitter profilinin internet adresi: https://twitter.com/dbdevletbahceli, Facebook profilinin adresi ise: https://www.facebook.com/milliyetcihareketpartisi olarak belirlenmiştir.

${ }^{16}$ Mukayeseli incelemelerin yapıldığı tarihte HDP yerine BDP (Barış ve Demokrasi Partisi) adı kullanılıyordu, o tarihteki BDP resmi internet sitesi (http://www.bdp.org.tr/tr/, Erişim Tarihi: 05.02.2014) yerine artık http://www.hdp.org.tr/ (Erişim Tarihi: 22.05.2015) adresi kullanilmaktadır.

${ }^{17}$ Sözü edilen sosyal medya hesapları 05.02.2014 tarihinde parti resmi internet sitesinde sağ alt blokta görüntülenmiştir. Partinin kurumsal sosyal medya adresleri Twitter: http://twitter.com/bdpsecim, Facebook: http://www.facebook.com/bdpsecim, Youtube: $\quad$ http://www.youtube.com/bdpsecim, Instagram: http://instagram.com/bdpsecim/ , Flickr: http://www.flickr.com/people/bdpsecim/, Tumblr: http://bdpsecim.tumblr.com/, LinkedIn: http://tr.linkedin.com/in/bdpsecim, Ustream: http://www.ustream.tv/user/bdpsecim olarak belirlenmiştir. 18 Tarama 28.05.2015 tarihinde belirtilen 4 partinin resmi internet sitelerinde yapılmıştır. Bkz. http://www.akparti.org.tr/site , http://www.chp.org.tr/ , http://www.mhp.org.tr/mhp_index.php , http://www.hdp.org.tr/ .
} 
seçimlerine yakın bir tarih olduğundan dolayı partilerin söz konusu sosyal medya hesaplarının da yoğun ve güncel olarak kullandıklarını belirtmek gerekmektedir.

Yapılan inceleme doğrultusunda sosyal medya kullanımının politika ve siyasette önem verilen bir konu olduğu kanısına varılmıştır. TBMM'de bulunan ve Türkiye'deki seçmen topluluğunun büyük kısmına hitap eden siyasi partilerin sosyal medya platformlarını kullanmaları, gelişen bu oluşumun siyaset ve politikayı da bünyesine kattığının açık bir işaretidir.

\section{ALAN ARAŞTIRMASI}

Alan araştırması bölümü, Hacettepe Üniversitesi İktisadi ve İdari Bilimler Fakültesi Siyaset Bilimi ve Kamu Yönetimi Bölümünün öğrencilerine uygulanan bir anket çalışmasından oluşmaktadır. Çalışma bu bölümde öğrenim görmekte olan lisans düzeyindeki öğrencilerin katılımı ile gerçekleştirilmiştir. Anket çalışmasında, geliştirilen bir anket soru formu, öğrencilere dağıtılmış ve katılımcılardan elde edilen veriler daha sonra analize tabi tutulmuştur. Alan araştırmasının bulgularının değerlendirilmesi sonucunda herhangi bir genelleme yapılmayacaktır. Ele alınan bulgular yalnızca araştırma grubunu ilgilendirmektedir. Araştırma grubu bir sonraki başlıkta daha ayrıntılı olarak tanımlanacaktır.

Araştırmanın temel amacı, çeşitli açılardan "Kamu Politikası ve Sosyal Medya İlişkisi”ni araştırmaktır. Bunun için; hazırlanan anket soruları aracılığıyla bu iki kavramın çeşitli boyutlardaki ilişkileri, ankete katılanların sorulara verdikleri cevaplar temelinde analiz edilmiştir.

\subsection{Araştırma Grubu}

Anket çalışması Hacettepe Üniversitesi İktisadi ve İdari Bilimler Fakültesi Siyaset Bilimi ve Kamu Yönetimi Bölümünün lisans düzeyinde öğrenim görmekte olan öğrencileri üzerinde gerçekleştirilmiştir. Anket formu, kamu politikası ve sosyal medya ilişkisini hem genel anlamda ve hem de Türkiye açısından değerlendirmeye yönelik 24 sorudan oluşmaktadır. Çalışmanın ölçeği, ağırlıklı olarak araştırmacı tarafından geliştirilmiştir. Ölçek geliştirilirken literatürde yer alan ve yapılan bu çalışmaya farklı açılardan benzerlik gösteren kaynaklardan ${ }^{19}$ da yararlanılmıştır. Anket, toplam 104 katılımcıya uygulanmış ve ardından analizler gerçekleştirilmiştir.

Anket çalışmasının yürütüldüğü araştırma grubu seçilirken şu kriterler esas alınmıştır:

- İnternet ve dolayısıyla sosyal medya kullanımının Türkiye'de en yoğun olduğu yaş grubu olan 16-24 yaş grubunu temsil etmektedir. ${ }^{20}$

- Siyaset Bilimi ve Kamu Yönetimi Bölümü öğrencileri geleceğin kamu politikası üretim süreçlerinde aktif olarak rol oynayabilecek bireylerdir.

- Siyaset Bilimi ve Kamu Yönetimi Bölümü öğrencileri, özellikle öğrenim gördükleri bölüm gereği sosyal medyayı, kamu politikasının takibi, yönlendirmesi ve duyurulması konusunda aktif olarak kullanabilme potansiyeline sahiptirler.

\footnotetext{
${ }_{19}$ GSB (2013). Gençlik ve Sosyal Medya Araştırma Raporu. T.C. Gençlik ve Spor Bakanlığı, Ankara Erişim: 19.01.2014, http://genclikarastirmalari.gsb.gov.tr/dergi/sosyal_medya_raporu/\#1/z

Pew/Internet (2008). "The Internet and the 2008 Election", Pew Internet \& American Life Project, Washington D.C., Erişim: 24.03.2014,

http://www.pewtrusts.org/uploadedFiles/wwwpewtrustsorg/Reports/Society_and_the_Internet/PIP_2008_election.pdf

${ }^{20}$ Türkiye İstatistik Kurumu'nun (TÜIK) Hanehalkı Bilişim Teknolojileri Kullanım Araştırması'na göre; 2013 yılı itibari ile 16-24 yaş aralığındaki genç bireylerin bilgisayar kullanım oranı $\% 70,6$ iken internet kullanım oranları $\% 68,7$ şeklinde belirlenmiştir. Bu oranlar 25-34 yaş aralığındaki yetişkinlerde bilgisayar kullanımı \%59,6 ve internet kullanımı \%58,8 şeklindedir. Bkz. Türkiye

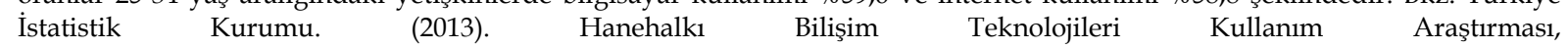
http://www.tuik.gov.tr/PreHaberBultenleri.do?id=13569, Erişim Tarihi: 10.05.2014. 


\subsection{Araştırmanın Kısıtlılıkları}

Araştırma sadece kamu politikası ve sosyal medya ilişkisini tespit etmeye yöneliktir. Çıkarsamalar tüm toplumu veya tüm sosyal medya kullanıcılarını kapsamamakta, sadece araştırmanın yapıldığı çalışma grubunu kapsamaktadır.

\subsection{Demografik Veriler}

Katılımcılara ilişkin demografik veriler aşağıdaki tablolarda özetlenmiştir.

Tablo 1. Katılımcıların Cinsiyet Grupları İtibariyle Dağılımı

\begin{tabular}{|l|r|r|r|r|}
\hline & \multicolumn{1}{|c|}{ Katılımc1 } & Yüzde & Geçerli Yüzde & Birikimli Yüzde \\
\hline Sayıs1 & & & 55,8 \\
Kadın & 58 & 55,8 & 55,8 & 100,0 \\
Erkek & 46 & 44,2 & 44,2 & \\
Toplam & 104 & 100,0 & 100,0 & \\
\hline
\end{tabular}

Tablo 2. Katılımcıların Sosyal Medya Kullanımları İtibariyle Frekans ve Yüzde Dağılımı

\begin{tabular}{|l|r|r|r|r|}
\hline & Frekans & Yüzde & Geçerli Yüzde & Birikimli Yüzde \\
\hline Evet & 102 & 98,1 & 98,1 & 98,1 \\
Hayır & 2 & 1,9 & 1,9 & 100,0 \\
Toplam & 104 & 100,0 & 100,0 & \\
\hline
\end{tabular}

Tablo 2. Katılımcıların En Sik Kullandıkları Sosyal Medya Platformları İtibariyle Dağılımı

\begin{tabular}{|l|r|r|r|r|}
\hline & \multicolumn{1}{|c|}{ Katılımc1 } & Yüzde & Geçerli Yüzde & Birikimli Yüzde \\
\hline Sayıs & & & \\
\hline Twitter & 57 & 54,8 & 55,9 & 55,9 \\
Youtube & 23 & 22,1 & 22,5 & 78,4 \\
Myspace & 15 & 14,4 & 14,7 & 93,1 \\
Instagram & 1 & 1,0 & 1,0 & 94,1 \\
Foursquare & 4 & 3,8 & 3,9 & 98,0 \\
Sözlükler & 1 & 1,0 & 1,0 & 99,0 \\
Toplam & 1 & 1,0 & 1,0 & 100,0 \\
Kullanmayan & 102 & 98,1 & 100,0 & \\
& 2 & 1,9 & & \\
Toplam & 104 & 100,0 & & \\
\hline
\end{tabular}


Tablo 3. Katılımcıların Sosyal Medyaya En Sık Bağlandıkları Cihazlar İtibariyle Dağılımı

\begin{tabular}{|l|r|r|r|r|}
\hline Cihaz & $\begin{array}{c}\text { Katılımc1 } \\
\text { Sayısı }\end{array}$ & Yüzde & Geçerli Yüzde & $\begin{array}{c}\text { Birikimli } \\
\text { Yüzde }\end{array}$ \\
\hline Masaüstü Bilgisayar & 8 & 7,7 & 7,8 & 7,8 \\
Dizüstü Bilgisayar & 42 & 40,4 & 41,2 & 49,0 \\
Tablet Bilgisayar & 2 & 1,9 & 2,0 & 51,0 \\
Akıllı Telefon & 50 & 48,1 & 49,0 & 100,0 \\
Toplam & 102 & 98,1 & 100,0 & \\
Kullanmayan & 2 & 1,9 & & \\
Toplam & 104 & 100,0 & & \\
\hline
\end{tabular}

Tablo 4. Katılımcıların Sivil Toplum Kuruluşlarına Üyelik Durumu İtibariyle Dağılımı

\begin{tabular}{|l|r|r|r|r|}
\hline & \multicolumn{1}{|c|}{ Katılımc1 } \\
Sayıs1 & Yüzde & Geçerli Yüzde & Birikimli Yüzde \\
\hline Üye & 24 & 23,1 & 23,5 & 23,5 \\
Üye Değil & 78 & 75,0 & 76,5 & 100,0 \\
Toplam & 102 & 98,1 & 100,0 & \\
Cevap & 2 & 1,9 & & \\
Yok & 104 & 100,0 & & \\
\hline
\end{tabular}

\subsection{Anket Formu}

Anket çalışmasına bir soru kağıdı hazırlanarak başlanmıştır. Ölçek geliştirme aşamasında öncelikle ulusal ve uluslararası literatür taranmış, çalışma konusu ile ilgili alan araştırmaları incelenmiştir. ${ }^{21}$ Literatürde bulunarak çalışmanın odak aldığı konuya katkıda bulunacağ düşünülen bazı sorular anket formuna dâhil edilmiştir.

Anket formunda Likert ölçeğine göre cevaplandırılması gereken 24 ifade yer almıştır. $\mathrm{Bu}$ ifadelerden 4'ü $(4,8,11,12$. sorular) Türkiye Cumhuriyeti Gençlik ve Spor Bakanlığı'nın “Gençlik ve Sosyal Medya Araştırma Raporu”ndan alınmıştır. İfadelerden 2'si ise (9 ve 10.

${ }^{21}$ GSB, (2013). Gençlik ve Sosyal Medya Araştırma Raporu. T.C Gençlik ve Spor Bakanlığı, Ankara Erişim: 19.01.2014, http://genclikarastirmalari.gsb.gov.tr/dergi/sosyal_medya_raporu/\#1/z

Türkiye İstatistik Kurumu. (2012). İstatistiklerle Gençlik 2012. Türkiye İstatistik Kurumu, Ankara. Pew/Internet. (2008). "The Internet and the 2008 Election", Pew Internet \& American Life Project, Washington D.C., Erişim: 24.03.2014, http://www.pewtrusts.org/uploadedFiles/wwwpewtrustsorg/Reports/Society_and_the_Internet/PIP_2008_election.pdf

Dewey, T., Kaden, J., Marks, M., Matsushima, S. and Zhu, B. (2012). The Impact of Social Media on Social Unrest in the Arab Spring. Stanford University, CA.

YnkLabs. (2013). Gezi Parkı İnografik. YnkLabs, Erişim: 05.05.2014, http://www.ynklabs.com/web/site/gezipark-infografik.pdf 
sorular) Pew Araştırma Merkezi'nin (The Pew Research Center) "İnternet ve 2008 Seçimleri”" (The Internet and the 2008 Election) isimli çalışmasından alınmıştır. Geriye kalan 18 ifade ise araştırmacı tarafından üretilmiştir. Kamu politikası ve sosyal medya ilişkisini farklı boyutlarda ölçmek için üretilmiş ifadelerden ilk 3'ü $(1,2$, 3. sorular) kamu politikası algısına, 4'ü $(4,5,6$, 7. sorular) sosyal medya algisına, 2'si (8 ve 19. sorular) internet kisitlamaları algisina, 12 'si (9, $10,11,12,13,14,15,16,17,18,20$ ve 21 ve 24 . sorular) sosyal medya ile kamu politikas1, politikacılar ve politik olaylar arasındaki bağlantıya ve 2'si (22 ve 23. sorular ) sosyal medyanın demokrasi ve buradan dolaylı olarak kamu politikasına katılım üzerindeki algısına ilişkin sorulardir.

\section{Tablo 5. Anket Formundaki İfadeler}

\begin{tabular}{|c|c|}
\hline 1 & $\begin{array}{l}\text { Halk hizmetinde bulunan devlet organlarının, toplumun tamamı ya da bir kısmı ile ilgili } \\
\text { aldığg kararları öğrenmek isterim. }\end{array}$ \\
\hline 2 & $\begin{array}{l}\text { Vatandaşlar, çeşitli yollarla bir araya gelerek devletin aldığı toplumsal kararları } \\
\text { etkileyebilirler. }\end{array}$ \\
\hline 3 & Devletin aldığı çoğu karar yine devlet tarafından toplumdan saklanmaktadır. \\
\hline 4 & $\begin{array}{l}\text { Haber alma konusunda sosyal medyayı radyo, televizyon ve gazete gibi geleneksel } \\
\text { medya araçlarından daha çok kullanırım. }\end{array}$ \\
\hline 5 & $\begin{array}{l}\text { Sosyal medyada görüşlerimi dile getirirken kendimi gerçek yaşamda olduğumdan daha } \\
\text { özgür hissediyorum. }\end{array}$ \\
\hline 6 & $\begin{array}{l}\text { Sosyal medyadan edindiğim bilgilerin doğruluğunu mutlaka kontrol eder, kaynağını } \\
\text { araştırırım. }\end{array}$ \\
\hline 7 & Sosyal medyada gündeme gelen haberler doğru bilgiler içermektedir. \\
\hline 8 & $\begin{array}{l}\text { Gerektiği hallerde hükümetler, sosyal medyaya erişimi sınırlandırabilir ve/veya } \\
\text { sansürleyebilir. }\end{array}$ \\
\hline 9 & Politik olayları sosyal medya üzerinden takip ederim. \\
\hline 10 & $\begin{array}{l}\text { Sosyal medyada siyasi görüşüm doğrultusunda haberler, yazılar, videolar ve } \\
\text { resimler gibi içerikleri listemdeki diğer kişilerle paylaşırım. }\end{array}$ \\
\hline 11 & Sosyal medya üzerinde etkinlik oluştururum. \\
\hline 12 & Sosyal medyada başkalarının oluşturdukları etkinliklere katılım gösteririm. \\
\hline 13 & $\begin{array}{l}\text { Sosyal medya listelerime politikacıları ve/veya devlet kurumlarını ekleyip takip } \\
\text { ederim. }\end{array}$ \\
\hline 14 & $\begin{array}{l}\text { Sosyal medya sayesinde politikacılar ile direkt iletişim kurarak sorunlarımı dile } \\
\text { getirebilirim. }\end{array}$ \\
\hline
\end{tabular}




\begin{tabular}{|l|l|}
\hline 15 & $\begin{array}{l}\text { Dünyada gelişen toplumsal olayları direkt olarak olay yerindeki kişilerden sosyal } \\
\text { medya aracılığı ile takip etmeye çabalarım. }\end{array}$ \\
\hline 16 & Arap Baharı sürecini sosyal medyadan takip ettim. \\
\hline 17 & Gezi Parkı Olaylarını takip ederken sosyal medyayı kullandım. \\
\hline 18 & $\begin{array}{l}\text { Gezi Parkı Olayları hakkında sosyal medyada paylaşımda bulundum. } \\
\text { iliskin konuşma, resim, video ve yazılı belgelerin sosyal medyada ifşa edilmesini } \\
\text { doğru buluyorum. }\end{array}$ \\
\hline 21 & $\begin{array}{l}\text { Her ne sebepten olursa olsun “devlet sırrı" niteliğindeki konuşma, yazışma ve } \\
\text { belgelerin sosyal medyada yayınlanması yanlıştır. }\end{array}$ \\
\hline 22 & $\begin{array}{l}\text { Sosyal medya kullanımının yaygınlaşması ile birlikte Türkiye daha demokratik bir } \\
\text { ülke haline gelmiştir. }\end{array}$ \\
\hline 23 & $\begin{array}{l}\text { Türkiye'de sosyal medya kullanımının yaygınlaşması zaman zaman kaos ortamı } \\
\text { yaratmaktan başka bir işe yaramamısı̆tır. }\end{array}$ \\
\hline 24 & $\begin{array}{l}\text { Türkiye'de sosyal medyada yer verilen toplumsal olaylar, halkın kamu politikasına } \\
\text { karşı duyarlılığını göstermektedir. }\end{array}$ \\
\hline
\end{tabular}

Anket soru formu, 1 (kesinlikle katılmıyorum) ile 5 (kesinlikle katılıyorum) arasında kademeli olarak değişen beşli Likert ölçeğinde düzenlenmiştir.

\subsection{Analiz}

Anket sorularının güvenirlik analizi Cronbach Alfa testi ile gerçekleştirilmiştir. Sorular sıralı (ordinal) ölçek tipi kabul edilen Likert ölçeğinde hazırlanmış olup, analizler her soru için ayrı olarak yapılmıştır. Araştırmada beşli Likert ölçeği kullanılmıştır.

Likert ölçekleme modeli, diğer modellere kıyasla daha sezgisel bir modeldir. Likert tipi ya da dereceleme toplamları tekniğine uygun bir ölçekte alınan puan, genel olarak ilgili ifadelere gösterilen tepkilere verilen ağırlıkların toplamlarından oluşmaktadır. ${ }^{22}$

\begin{tabular}{|r|r|}
\hline $\begin{array}{c}\text { Cronbach Alfa } \\
\text { Katsayis1 }\end{array}$ & Soru Say1s1 \\
\hline 0,844 & \\
\hline
\end{tabular}

22Tezbaşaran, A. A. (2008). Likert Tipi Ölçek Hazırlama Klavuzu. 3. Sürüm, E-Kitap, Erişim Tarihi: 16.05.2014, https://www.academia.edu/1288035/Likert_Tipi_Olcek_Hazirlama_Kilavuzu 
Yukarıda da görüldüğü üzere anket sorularının Cronbach alfa değeri 0,844 olarak saptanmıştır. $\mathrm{Bu}$ değer istatistik literatüründe "yükssek derecede güvenilirliği" temsil etmektedir.

\subsection{Araştırma Soruları}

Anket çalışmasında aşağıdaki sorulara yanıt aranmıştır.

1. Katılımcılar tarafindan, sosyal medya oluşumu kamu politikasına bir etki aracı olarak görülmekte midir?

2. Katılımcıların STK'lara üyelik durumu ile sosyal medyada kamu politikasına karşı etkinlik oluşturmaları/etkinliğe katılmaları arasında anlamlı bir ilişki bulunmakta mıdır?

3. Katılımcılar kamu politikasına sosyal medya aracılığı ile etki edebileceklerine inanmakta midir?

4. Katılımc1lar sosyal medyadan edindikleri bilgilere güvenmekte midir?

5. Katılımcilar kamu politikasından haberdar olmak istemekte midir?

6. Katılımcıların, devletin interneti kısıtlayıcı politikalarına karşı tutumları ne yöndedir? $\mathrm{Bu}$ tutumlar ile katılımcıların kamu politikasına duyarlılıkları arasında anlamlı bir ilişki var mıdır?

7. Katılımcılar kamu politikasına tepki amacıyla sosyal medya üzerinde örgütlenmekte midir?

8. Katılımcılar sosyal medyayı geleneksel medyaya tercih etmekte midir?

9. Katılımcılar politik olayların takibi konusunda sosyal medyayı kullanmakta mıdır?

10. Katılımcılar politikacılara ulaşmada sosyal medyayı kullanmakta mıdır?

11. Katılımcılar ulusal ve uluslararası politik olayları sosyal medya aracılığı ile takip etmekte midir? Bu olaylara karşı sosyal medya üzerinden görüş bildirmekte midir?

12. Sosyal medya, kamu politikası ve toplumsal olaylara tepki konusunda katılımcıları teşvik etmekte midir?

13. Katılımcıların sosyal medya-demokrasi ve sosyal medya-kaos ilişkilendirmeleri üzerindeki algıları ne yöndedir? Bu algılar arasında nasıl bir karşılaştırma yapılabilir?

14. Katılımcılar "devlet sırrı" niteliğindeki konuşma, yazışma ve belgelerin sosyal medyada yayınlanmasına nasıl bakmaktadır?

15. Katılımcılar toplumu ilgilendiren konularda politikacıların özel hayatlarına ilişkin konuşma, resim, video ve yazılı belgelerin sosyal medyada ifşa edilmesine nasıl bakmaktadır?

16. Katılımcıların tamamı Arap Baharı sürecini sosyal medyadan takip etmiş midir?

17. Katılımcıların tamamı Gezi Parkı Olaylarını sosyal medyadan takip etmiş midir?

18. Katılımcıların sosyal medyada yer alan olaylar ile halkın kamu politikasına karşı duyarlılığına ilişkin algısı ne yöndedir?

19. Katılımcılar sosyal medya aracılığıyla devlet kurumlarını takip etmekte midir?

\subsection{Bulgular}

Verileri analiz etmek amaciyla ankette yer alan ifadeler maddeler altında gruplanacak ve her ifade için bulgular ayrı ayrı verilecektir. Bu ifadelere verilen cevaplar ölçülürken "çapraz tablolama" yapılacaktır. Çapraz tablolamada ifadelere verilen cevaplar çalışmanın önceki bölümlerinde bir kamu politikası aktörü olarak ele alınan STK'lardan yola çıkarak, "STK'lara üyelik durumu" bağımsız değişkeni ile karşılaştırılacaktır. Tablolarda kişi sayılarına ve yüzdelere yer verilecektir.

1. "Halk hizmetinde bulunan devlet organlarının, toplumun tamamı ya da bir kısmı ile ilgili aldığı kararları öğrenmek isterim" sorusuna STK üyesi olan katılımcıların \%11,5'i "Katılıyorum", \%84,6“s1 "Kesinlikle Katılıyorum" cevabını vermişlerdir. STK üyesi olmayan katılımcilarda da bu oran \%20,5 "Kat1lıyorum", \%74,4 "Kesinlikle Katıllyorum" olarak ölçülmüştür. Genel olarak katılımcıların tamamı göz önüne alındığında, katılımcıların \%18,3’ü 
bu soruya "Katılıyorum", \%76,9'u ise "Kesinlikle Katılıyorum" cevabını vermişlerdir. Dolayısıyla katılımcıların kamu politikasını öğrenme talebi yüksektir.

2. "Vatandaşlar, çeşitli yollarla bir araya gelerek devletin aldığı toplumsal kararları etkileyebilirler" sorusuna STK üyesi ve STK üyesi olmayan katılımcıların \%45,2'si “Kesinlikle Katılıyorum" ve \%41,3'ü "Katılıyorum" cevabını vermişlerdir. Verilen cevapların oranları arasında katılımcıların STK üyesi olup olmamasına bağlı olan önemli bir fark ölçülmemiştir. Katılımcılar genel olarak kamu vatandaşların bir araya gelerek kamu politikasını etkileyebileceğine inanmaktadırlar.

3. "Devletin aldığı çoğu karar yine devlet tarafından toplumdan saklanmaktadır" sorusuna STK üyesi olan katılımcıların yarısına yakını kararsız kalmıştır. Bu oran STK üyesi olmayan katılımcılarda ise $\% 20,5$ oranında ölçülmüştür.

4. "Haber alma konusunda sosyal medyayı; radyo, televizyon ve gazete gibi geleneksel medya araçlarından daha çok kullanırım" sorusuna genel olarak katılımcılar toplamda (Katılıyorum + Kesinlikle Katılıyorum) \%75 oranında olumlu yanıt verirken; STK üyesi olan katılımcılar STK üyesi olmayan katılımcılara göre daha olumsuz yanıtlar vermişlerdir. Sorunun değiştirilerek alındığı GSB Sosyal Medya Araştırma Raporu'nda bu soruya ${ }^{23} \% 63,75$ oranında olumlu yanıt verilmiştir.

5. "Sosyal medyada görüşlerimi dile getirirken kendimi gerçek yaşamda olduğumdan daha özgür hissediyorum" sorusuna "Kararsızım" cevabını verenler ayrı tutulduğunda katılımcıların \%50'sinin üzerindeki kısmı olumsuz cevap vermiştir. Bu durum katılımcıların sosyal medya platformları üzerinde gerçek yaşamda olduklarından daha özgür hissetmediklerini göstermektedir. Bu oranların katılımcıların STK'lara üyelik durumlarına göre de önemli bir farklılık göstermediği belirlenmiştir.

6. "Sosyal medyadan edindiğim bilgilerin doğruluğunu mutlaka kontrol eder, kaynağını araştırırım" sorusuna STK üyelik durumu önemli bir farklılık göstermeksizin katılımcıların geneli olumlu cevap vermiştir. Katılımcılar tarafından "Katıllyorum" ve "Kesinlikle Katılıyorum” olarak verilen cevapların toplamı \%86,9 olarak hesaplanmıştır.

7. "Sosyal medyada gündeme gelen haberler doğru bilgiler içermektedir" sorusuna katılımcıların hiç biri "Kesinlikle Katılıyorum" cevabı vermemiştir. Katılımcıların yarısına yakını STK'lara üyelik durumu önem teşkil etmeksizin "Kararsızım” yanıtını vermiştir. Bu verilerden anlaşılacağı üzere; katılımcılar sosyal medyada gündeme gelen haberlerin doğru bilgiler içerdiklerine inanmamaktadır.

8. "Gerektiği hallerde hükümetler, sosyal medyaya erişimi sınırlandırabilir ve/veya sansürleyebilir” sorusuna katılımcıların \%43,3'ü "Kesinlikle Katılmıyorum” cevabını vermekle birlikte; \%18,3'ü de "Katılmıyorum” cevabını vermiştir. Buna karşın STK üyesi katılımcıların toplamda \%57,7'si olumsuz (Katılmıyorum+Kesinlikle Katılmıyorum) cevap verirken, STK üyesi olmayan katılımcıların toplamda \%62,8'i olumsuz cevap vermiştir. Ankete katılan katılımcıların çoğunluğu internet sınırlama ve sansürlemelerini doğru bulmamaktadır. GSB Gençlik ve Sosyal Medya Araştırma Raporu'nda ulaşılan sonuçlarda da ise bu soruya olumlu; yani hükümetlerin gerekli hallerde internet kısıtlaması uygulayabileceğini onaylayan katılımcı oran1 \% 42,95 'dir. ${ }^{24}$

9. "Politik olayları sosyal medya üzerinden takip ederim" sorusuna katılımcıların \%70'den fazlası "Katılıyorum" ya da "Kesinlikle Katılıyorum" cevabını vermiştir. Sorunun alındığı Pew

\footnotetext{
${ }^{23 B}$ Bahsi geçen soru alıntı yapılan kaynakta "Sosyal medya alternatif medyanın (tv, gazete, radyo) alternatifidir" şeklindedir. Bkz. GSB, (2013). Gençlik ve Sosyal Medya Araştırma Raporu. T.C Gençlik ve Spor Bakanlığı, Ankara Erişim Tarihi: 19.01.2014, http://genclikarastirmalari.gsb.gov.tr/dergi/sosyal_medya_raporu/\#1/z

${ }^{24}$ GSB, (2013). Gençlik ve Sosyal Medya Araştırma Raporu. T.C Gençlik ve Spor Bakanlığı, Ankara Erişim Tarihi: 19.01.2014, http://genclikarastirmalari.gsb.gov.tr/dergi/sosyal_medya_raporu/\#1/z
} 
Araştırma Merkezi'nin “İnternet ve 2008 Seçimleri” isimli çalışmasında da aynı soruya aynı eğitim seviyesindeki katılımcılar \%58 oranında olumlu cevap vermişlerdir. ${ }^{25}$ Dolayısıyla iki çalışmanın anketine katılan katılımcılar farklı ülkelerden olmasına karşın yüksek bir oranla politik olayların sosyal medya üzerinden takip ettiklerini ifade etmişlerdir.

10. "Sosyal medyada siyasi görüşüm doğrultusunda haberler, yazılar, videolar ve resimler gibi içerikleri listemdeki diğer kişilerle paylaşırım" sorusuna katılımcıların \%50' den daha büyük bir kısmı çekimser ya da olumsuz cevaplar verirken; \%25'i "Katılıyorum”, \%14,4'ü ise kesinlikle katılıyorum cevabını vermiştir. STK üyesi olan katılımcıların olumlu cevaplarının toplam yüzdeleri STK üyesi olmayan katılımcılara göre daha yüksektir. Bu soruya Pew Araştırma Merkezi'nin “İnternet ve 2008 Seçimleri” isimli çalışmasında yetişkin katılımcıların \%5'i olumlu cevap vermiştir.

11. "Sosyal medya üzerinde etkinlik oluştururum" sorusuna katılımcıların \%80'inden fazlası olumsuz cevap vermiştir. Dolayısıyla bu sonuçlardan katılımcıların büyük çoğunluğunun sosyal medya üzerinden etkinlik oluşturmayı tercih etmedikleri anlaşılmıştır. GSB Gençlik ve Sosyal Medya Araştırma Raporu'nda ${ }^{26}$ katılımcıların \%46,6'sı bu soruya olumlu cevap vermiştir. Bu iki bulgu arasında önemli bir farklılığın bulunduğu dikkat çekmektedir.

12. "Sosyal medyada başkalarının oluşturdukları etkinliklere katılım gösteririm" sorusuna katılımcıların yarısına yakını olumlu cevap vermiştir. Kararsız kalan katılımcıların oranı ise \%22,1'dir. STK üyesi katılımcıların toplam olumlu cevaplarının (Katılıyorum+Kesinlikle Katılıyorum) oranı STK üyesi olmayan katılımcılarınkine göre daha yüksektir. GSB Gençlik ve Sosyal Medya Araştırma Raporu'nda ${ }^{27}$ bu soruya olumlu cevap verenlerin oran $1 \% 66,5$ 'tir. 13. "Sosyal medya listelerime politikacıları ve/veya devlet kurumlarını ekleyip takip ederim" sorusuna katılımcıların önemli bir kısmı olumlu cevap vermiştir. Katılımcıların \%40,8' "Katılıyorum", \%26,2'si ise "Kesinlikle Katılıyorum" cevabını vermiş olması, katılımcıların politikacıları ve devlet kurumlarını sosyal medya aracılığıyla takip etme eğiliminde olduğunu göstermektedir.

14. "Sosyal medya sayesinde politikacılar ile direkt iletişim kurarak sorunlarımı dile getirebilirim" sorusuna katılımcılar \%50’lik bir oranla olumsuz cevap vermiştir. Katılımcılar sosyal medya aracılığıyla politikacılarla direkt iletişim kurabileceklerine inanmamaktadırlar.

15. "Dünyada gelişen toplumsal olayları direkt olarak olay yerindeki kişilerden sosyal medya aracılığı ile takip etmeye çabalarım” sorusuna katılımcıların \%48,1'i “Katılıyorum”, \%16,3'ü "Kesinlikle Katılıyorum" cevabını vermiștir. Bu durum STK üyesi olan ya da olmayan katılımcılarda önemli bir değişiklik göstermemiştir.

16. "Arap Baharı sürecini sosyal medyadan takip ettim" sorusuna katılımcıların yaklaşık \%50'si olumlu cevap vermiştir. Bu durumda kullanıcıların STK üyelik durumunun önemli bir etkisi görülmemektedir.

17. "Gezi Parkı Olaylarını takip ederken sosyal medyayı kullandım" sorusuna katılımcılar toplamda (Katıliyorum+Kesinlikle Katılıyorum) \%83,6 oranında olumlu cevap vermiştir. Katılımcıların STK'lara üyelik durumunun oranlara önemli bir fark yaratacak etkisi olmamıştır.

${ }^{25}$ Bkz. Pew/Internet. (2008). "The Internet and the 2008 Election", Pew Internet \& American Life Project, Washington D.C., Erişim Tarihi:

24.03.2014,

http://www.pewtrusts.org/uploadedFiles/wwwpewtrustsorg/Reports/Society_and_the_Internet/PIP_2008_election.pdf

${ }^{26}$ GSB, (2013). Gençlik ve Sosyal Medya Araştırma Raporu. T.C Gençlik ve Spor Bakanlığı, Ankara Erişim Tarihi: 19.01.2014, http://genclikarastirmalari.gsb.gov.tr/dergi/sosyal_medya_raporu/\#1/z

${ }^{27 G S B}$, (2013). Gençlik ve Sosyal Medya Araştırma Raporu. T.C Gençlik ve Spor Bakanlığı, Ankara Erişim Tarihi: 19.01.2014, http://genclikarastirmalari.gsb.gov.tr/dergi/sosyal_medya_raporu/\#1/z 
18. "Gezi Parkı Olayları hakkında sosyal medyada paylaşımda bulundum" sorusuna katılımc1lar \%26 oranında "Katılıyorum", \%26,9 oranında "Kesinlikle Katılıyorum" cevabını vermiştir. Bu oranların toplamları STK üyesi olan katılımcılarda daha yüksek ölçülmüştür.

19. "Türkiye'de yapılan internet kısıtlama ve yasaklarını doğru bulmuyorum" sorusuna katılımcıların yarısından çoğu "Kesinlikle Katılmıyorum" cevabını vermiştir. Buradan görüleceği üzere; tüm olumlu cevaplar göz önüne alındığında, katılımcıların büyük çoğunluğu Türkiye'deki internet kısıtlama ve yasaklarını doğru bulmamaktadır.

20. "Toplumu ilgilendiren konularda olduğu takdirde politikacıların özel hayatlarına ilişkin konuşma, resim, video ve yazılı belgelerin sosyal medyada ifşa edilmesini doğru buluyorum" sorusuna STK üyesi katılımc1lar toplamda (Katılmıyorum+Kesinlikle Katılmıyorum) \%53,8 oranında, STK üyesi olmayan katılımcılar \%51,3 oranında olumsuz cevap vermişlerdir. Katılımcıların tümü bu soruya \%17,3 oranında "Katılıyorum", \%16,3 oranında "Kesinlikle Katılıyorum" cevabını vermiştir. Bu sonuçlar doğrultusunda anlaşılacağı üzere STK üyesi olan ya da olmayan katılımcıların çoğunluğu politikacıların özel hayatlarının ifşa edilmesini yanlış bulmaktadır.

21. 'Her ne sebepten olursa olsun 'devlet sırrı' niteliğindeki konuşma, yazışma ve belgelerin sosyal medyada yayınlanması yanlıştır” sorusuna katılımcılar \%60'ın üzerinde (Katılıyorum+Kesinlikle Katılıyorum) olumlu cevap vermiştir. Verilen bu cevaplar katılımcıların STK'lara üyelik durumu önemli bir fark yaratmamıştır. Soruya kararsız kalanların oranı \%21,2'dir. Direkt olarak olumsuz cevap veren katılımcıların sayısı oldukça azdır. Sonuçlardan anlaşılacağı üzere katılımcıların büyük bir çoğunluğu "devlet sırrı" niteliğindeki belgelerin sosyal medya üzerinde yayınlanmasını yanlış bulmaktadır.

22. "Sosyal medya kullanımının yaygınlaşması ile Türkiye daha demokratik bir ülke haline gelmiştir" sorusuna katılımcılar \%30,8 oranında "Kararsızım" ve yine \%30,8 oranında "Katılıyorum" cevabını vermiştir. Dikkat çekici olarak; bu oranlar STK üyesi olan ve olmayan üyelerin cevaplarında Kararsızım" ve "Katılıyorum" cevaplarında eşit çıkmıştır.

23. "Sosyal medya kullanımının yaygınlaşması zaman zaman kaos ortamı yaratmaktan başka bir işe yaramamıştır" sorusuna katılımcıların yarısına yakın bir kısmı olumlu cevap vermiştir. Kararsız olan katılımcıların oranı da \%27,9 olup; azımsanmayacak bir niteliktedir.

24. "Türkiye'de sosyal medyada yer verilen toplumsal olaylar, halkın kamu politikasına karşı duyarlılığını göstermektedir" sorusuna katılımcılar \%60'ın üzerinde bir oranla olumlu cevap vermiştir. Sonuçlar; sosyal medyada yer alan olayların kamu politikasına karşı olan duyarlılığın bir göstergesi olarak algılandığını göstermektedir.

\subsection{Tartışma}

Çalışmada kullanılan anket sorularının 7'si iki benzer çalışmadan aynen ya da değiştirilerek alınmıştır. Analiz sonucunda elde edilen bulgular karşılaştırıldığında gerçekleştirilen bu çalışma ve diğer iki çalışmada elde edilen sonuçlar arasında büyük benzerlikler ve aynı zamanda bir takım farklılıklar ortaya çıkmıştır. Bu karşılaştırmalarda ortaya çıkan bulgular aşağıda incelenecektir. Bulgular karşılaştırılırken çalışmaların birbiri ile karıştırılmaması için yararlanılan iki çalışma “GSB'nin çalışması" ve "ABD'de yapılan çalışma”, bu çalışma üzerinde yapılan alan araştırması ise "araştırmacı tarafından yapılan çalışma" olarak adlandırılacaktır.

Araştırmacı tarafından yapılan çalışmada, "Gerektiği hallerde hükümetler, sosyal medyaya erişimi sınırlandırabilir ve/veya sansürleyebilir" sorusunda, iki çalışma arasında elde edilen bulgularda yüksek bir oranda olmasa da, çoğunlukta yer alan cevaplar açısından farklılık gözlemlenmiştir. GSB'nin raporunda elde edilen bulgulara göre katılımcıların \%42,95 oranındaki çoğunluğu, hükümetlerin gerekli hallerde internete sınırlama ya da sansür uygulamasını doğru bulurken, araştırmacının yaptığı anket sonuçlarında ise katılımcıların toplamda \%61,6'sı bu uygulamayı yanlış bulmaktadır. GSB'nin raporunda belirtilen oranın, 
çoğunluk olarak kabul edilmesinin nedeni kararsız katılımcılarının oranının \%21,9 olmasıdır. Araştırmacının yaptığı ankette ise bu oran \%8,7 olarak ölçülmüştür. Dikkat çekici bir diğer veri, araştırmacının elde ettiği bulgularda STK üyesi olan kararsız katılımcının bulunmamasıdır. Bu veriler doğrultusunda; ortaya çıkan bu farklılığın, iki araştırmada yer alan katılımcılardaki yaş aralığı ve eğitim düzeyindeki farklılıkların yanı sıra, araştırmacının grubunda yer alan üniversite öğrencilerinin daha kararlı cevaplar vermesinden kaynaklandığı düşünülmektedir.

"Sosyal medyada siyasi görüşüm doğrultusunda haberler, yazılar, videolar ve resimler gibi içerikleri listemdeki diğer kişilerle paylaşırım" sorusuna araştırmacının bulgularına göre katılımcıların \%50'den daha büyük bir kısmı çekimser ya da olumsuz cevaplar verirken; toplamda \%39,4'lük bir kısmı ise olumlu cevaplar vermiştir. Bu soruya Pew Araştırma Merkezi'nin “İnternet ve 2008 Seçimleri” isimli çalışmasında aralarında yetişkinlerin de olduğu katılımcıların \%5'i olumlu cevap vermiştir. Sonuçlar arasında görülen farklılığın nedeni olabilecek üç durum söz konusudur: İlk durum; ABD'de yapılan araştırmanın sosyal medyanın aktif olmaya henüz başladığı 2008 yılında yapılmasıdır. Bunun yanında, araştırmalarda elde edilen bulguların farklılık göstermesinde, ülkelerin o dönemdeki gündemlerinin önemi de vardır. Örneğin, toplumsal bir olay karşısında, henüz internet sansürleri uygulanmış ve siyasi görüşler doğrultusunda paylaşımda bulunanlara sıkı yaptırımlar uygulanmış bir ülkede, izleyen dönemlerde bireylerin siyasi görüşleri doğrultusunda paylaşımda bulunma yoğunluğu azalacaktır. Bu doğrultuda, alan araştırmasında yer alan iki ülke açısından bu durum göz önünde bulundurulmalıdır. Araştırmanın yapıldığı zaman diliminde Türkiye'de internet sansür ve sınırlamaları gerçekleşmiştir. İkinci durum ise katılımcıların 18 yaş ve üzeri seçmen niteliğindeki bireyleri kapsamasıdır. Son durum ise; bireylerin "özdenetim"leri arasında var olan farklılıklardır. Burada söz konusu olan özdenetim; bireylerin, sosyal medya üzerinde yaptıkları paylaşımların sonuçları üzerinde düşünerek devletten önce kendileri tarafından uyguladıkları sansürü nitelemektedir. Bireylerce yapılan bu özdenetim, onların içinde bulundukları ortam, eğitim düzeyleri, vatandaşı oldukları ülkelerin rejimi, içinde bulunulan zamanın gündemine farklılık gösterecektir. Ülkelerin rejimleri, kişilerin kamu politikaları ve siyasi konularla ilgili düşüncelerini paylaşma özgürlüğü konusunda doğrudan etkilidir. Bireylerin eğitim düzeyleri de kişilerin kendilerini ifade edebilmesinde etkili olan bir faktördür. Sıralanan değişkenler arasından en büyük öneme sahip olan faktör ise ülke ve siyaset gündemidir. Bireylerin sosyal medyada yapacakları paylaşımlar, gündeme göre şekillenecektir. $\mathrm{Bu}$ çerçeveden bakıldığında; yapılan araştırmalarda karşılaşılan farklı bulguların, bireylerin özdenetimine ve onu etkileyecek olan faktörlerin yoğunluğuna göre değişiklik göstermiş olması düşünülmektedir.

"Sosyal medya üzerinde etkinlik oluştururum" sorusuna araştırmacının bulgularında katılımciların \%80'inden fazlası olumsuz cevap verirken; GSB'nin Raporu'nda ${ }^{28}$ katılımciların \%46,6's1 bu soruya olumlu cevap vermiştir. Bu iki bulgu arasında önemli bir farklılı̆̆ın bulunduğu dikkat çekmektedir. Bu soru katılımcıların sosyal medya üzerinden çeşitli etkinlik ve amaçlar doğrultusunda örgütlenmeye yönelik tutumlarını ölçmek amacıyla sorulmuştur. İki çalışmada yer alan ve farklı demografik özelliklere sahip olan katılımcıların "etkinlik" kelimesi ile zihinlerinde farklı algılar oluştuğu düşünülmektedir. Araştırmacının anketine katılan SBKY öğrencilerinin, hem okudukları bölümden hem de anketin "kamu politikası" ile ilgili olmasından dolayı, "etkinlik" kelimesini "siyasi bir etkinlik" olarak düşünerek olumsuz cevap vermiş olmaları muhtemeldir. Diğer yandan GSB'nin çalışmasındaki politik sorular, günlük hayata ilişkin birçok soru ile birlikte verilmiştir. Bu ankete 15-17 yaş arası bireylerin de

${ }^{28}$ GSB, (2013). Gençlik ve Sosyal Medya Araştırma Raporu. T.C Gençlik ve Spor Bakanlığı, Ankara Erişim Tarihi: 19.01.2014, http://genclikarastirmalari.gsb.gov.tr/dergi/sosyal_medya_raporu/\#1/z 
katıldı̆̆ı göz önüne alındığında, “etkinlik” kelimesine karşı gerçekleşmiş bir algı farklılığ1 olması muhtemeldir.

"Sosyal medyada başkalarının oluşturdukları etkinliklere katılım gösteririm" ifadesine katılımcıların yarısına yakını olumlu cevap verirken; kararsız kalan katılımcıların oranı ise \%22,1 olarak ölçülmüştür. GSB'nin Raporu'nda bu soruya olumlu cevap verenlerin oranı \%66,5'tir. Yukarıdaki paragrafta ele alınan varsayım burada da geçerli olmakla birlikte söz konusu muhtemel algı farklılığı da göz önüne alındığında iki araştırma sonucunda elde edilen bulgular büyük oranda örtüşmektedir.

"Politik olayları sosyal medya üzerinden takip ederim" ifadesine katılımcıların yaklaşık \%70'i "Katılıyorum" ya da "Kesinlikle Katılıyorum" cevabını vermiştir. Sorunun alındığı Pew Araştırma Merkezi'nin “İnternet ve 2008 Seçimleri” isimli çalışmasında da aynı soruya aynı eğitim seviyesindeki katılımcılar \%58 oranında olumlu cevap vermişlerdir. ${ }^{29}$ Araştırmacının yaptığı çalışmada elde edilen bulgularda karşılaşılan \%12 oranındaki fazlalığın katılımcıların Siyaset Bilimi ve Kamu Yönetimi (SBKY) bölümü öğrencisi olmalarından kaynaklandığ düşünülmektedir. Söz konusu düşünceye göre bu öğrencilerin politik olaylara karş1 daha ilgili olması beklenmektedir. Sonuç olarak; çalışmaların anketine katılan katılımcıların farklı ülkelerden olmasına ve sosyal medyanın ABD'de daha eski bir geçmişe dayanmasına karşın, sonuçların birbirine yakın çıktığı ve araştırma sonuçlarının örtüştüğü gözlemlenmektedir.

"Haber alma konusunda sosyal medyay1; radyo, televizyon ve gazete gibi geleneksel medya araçlarından daha çok kullanırım" sorusuna katılımcılar \%75 oranında olumlu yanıt vermişlerdir. Orijinal hali "Sosyal medya, geleneksel medyanın alternatifidir" olan ifadenin değiştirilerek alındığ 1 GSB'nin ${ }^{30}$ raporunda bu soruya $\% 63,75$ oranında olumlu yanıt verilmiştir. Bu farklılığın, araştırmalardaki soruları cevaplayan katılımcıların demografik özelliklerindeki farklılıktan dolayı ortaya çıktığı düşünülmektedir. GSB'nin çalışmasındaki ankete 15-29 yaş aralığında bulunan 2.057 kişi katılmıştır. Bu çalışmada ise katılımcılar, lisans düzeyinde eğitim görmekte olan ve ağırlıklı olarak 18-24 yaş aralığında bulunan katılımcılardır. Katılımcıların yaşlarında ortaya çıkan bu farklılık, eğitim düzeylerini de etkilemektedir. GSB'nin aynı çalışmasında yaşa ve son mezun olunan okula göre sosyal medya kullanım sıklıklarını yansitan bulgulara yer verilmiştir. Bulgulara göre; sosyal medyayı her gün kullanan 15-17 yaş aralığındaki gençlerin oranı \%83,9 iken, 18-24 yaş aralığındaki gençlerde bu oran \%86,6 olarak ölçülmüştür. Aynı şekilde en son ortaöğretimden mezun olan ve sosyal medyayı her gün kullanan gençlerin oranı \%81,1 iken, Yükseköğretimden mezunu olan gençlerde bu oran \% 87,9 olarak ölçülmüştür. Görüldüğ̈̈ gibi oranlar, 18-24 yaş arası gençlerde daha yüksek ölçülmüştür. Dolayısıyla, iki çalışma arasında ortaya çıkan farklılığın katılımcıların yaş aralığı ve eğitim seviyelerinden kaynaklandığı varsayımı doğruluk kazanmakta olup; iki çalışmanın bulgularının bu çerçevede büyük ölçüde örtüşmekte olduğu gözlemlenmektedir.

Araştırmacı tarafından elde edilen bulgularda, katılımcılar ulusal ve uluslararası toplumsal olayları sosyal medya aracılığıyla takip etmişlerdir. Bulgulara göre Gezi Parkı olaylarını sosyal medya üzerinden takip eden katılımcıların oranı \%80'in üzerindedir. Katılımcıların yarısına yakın bir kısmı da Arap Baharı'nı bu oluşum üzerinden takip etmiştir. Söz konusu politik

\footnotetext{
${ }^{29 B k z . ~ P e w / I n t e r n e t . ~(2008) . ~ " T h e ~ I n t e r n e t ~ a n d ~ t h e ~} 2008$ Election", Pew Internet \& American Life Project, Washington D.C., Erişim Tarihi: 24.03.2014,

http://www.pewtrusts.org/uploadedFiles/wwwpewtrustsorg/Reports/Society_and_the_Internet/PIP_2008_election.pdf

${ }^{30}$ Bahsi geçen soru alıntı yapılan kaynakta "Sosyal medya alternatif medyanın (Tv, gazete, radyo) alternatifidir" şeklindedir. Bkz. GSB, (2013). Gençlik ve Sosyal Medya Araştırma Raporu. T.C Gençlik ve Spor Bakanlığı, Ankara Erişim Tarihi: 19.01.2014, http://genclikarastirmalari.gsb.gov.tr/dergi/sosyal_medya_raporu/\#1/z
} 
olayları sosyal medya üzerinden takip etme davranışında karşılaşılan sonuçlar, ABD'de 2008 yılında yapılan araştırma bulgularında elde edilen \%40'lık oranla örtüşmektedir. ${ }^{31}$

Yapılan üç araştırmada; katılımcılar, zaman ve ortam yönünden farklılıklar bulunmasına rağmen, ortaya çıkan bulgular büyük oranda örtüşmektedir. Araştırmacı tarafından gerçekleştirilen analizler sonucunda elde edilen bulgular genel olarak sosyal medya ve kamu politikası arasında kuvvetli bir ilişkinin varlığını ortaya koyarken; sosyal medya kullanımının yoğun olduğu ancak bu platformda yer alan bilgilere güvenme konusunda katılımcıların kararsız olduğu ortaya çıkmıştır. Buna paralel olarak kullanıcılar, sosyal medyanın Türkiye'de daha demokratik bir ortam oluşturduğu ya da kaos ortamı yarattığı konusunda kararsız kalmışlardır. Katılımcıların kamu politikasını öğrenme talepleri son derece yüksektir. Bunun yanında katılımcılar, bu politikaların devlet tarafından kendilerinden saklandığını düşünmektedirler. STK üyesi olan kullanıcılar bu konuda daha kararsız bir durumdadırlar. Kitlelerin bir araya gelerek kamu politikasını etkileyebileceğine inancı neredeyse tam olan kullanıcılar, sosyal medya üzerinden etkinlik oluşturmaya sıcak bakmasalar da; sosyal medya üzerinden oluşturulan etkinliklere katılım göstermektedirler. Katılımcılar, kamu kurumlarını ve politikacıları sosyal medya üzerinden takip etmektedir, fakat onlarla doğrudan iletişim kuramadıkları konusunda hemfikirlerdir.

Katılımcılar internet kısıtlamaları ve yasaklarını genel olarak doğru bulmamaktadır. Bu konuda, STK üyesi olan katılımcıların kısıtlamaları doğru bulmak ya da bulmamak konusunda birbirlerinden ayrıldığı gözlemlenmiştir. Söz konusu katılımcılar, kamu politikasını öğrenme, onlardan haberdar olma konusunda daha istekli olarak gözlemlenmiştir. Gezi Parkı Olaylarını sosyal medya üzerinden takip konusunda da bu kullanıcılar daha aktif olmuşlardır.

\section{Sonuç}

Kamu Politikası ve Sosyal Medya ilişkisinin farklı boyutları üzerinde üniversite öğrencilerinin algısını ölçmek üzere gerçekleştirilen alan araştırmasının sonuçları şu şekilde sıralanabilir:

- Gençler, kamu politikalarından haberdar olmak istemekte ve bu konuda sosyal medyayı bir araç olarak görmektedirler. Bu amaçla, devlet kurumlarını ve politikacıları sosyal medya hesaplarına eklemekte ve takip etmektedirler.

- Gençler, sosyal medya oluşumunu, kamu politikasına bir etki aracı olarak görmektedir. Gerçekten de kamu politikası ve sosyal medya arasında karşılıklı bir ilişki olduğu görülmektedir. Devlet sosyal medya politikaları üretebildiği gibi, sosyal medya da güçlü bir iletişim ve haberleşme aracı olarak devletin ürettiği kamu politikasını etkileyebilmektedir.

- Gençler, sosyal medya üzerinde oluşturulan etkinliklere katılmayı, bu etkinlikleri oluşturmaktan daha çok tercih etmektedir. Bu durum gençlerin sosyal medya üzerinden pasif olarak örgütlenme eğiliminde olduklarını göstermektedir.

- Sosyal medya üzerinden etkinlik oluşturma ve oluşturulan etkinliklere katılma eğilimlerinde gençlerin STK üyesi olup olmamasının bir etkisi yoktur. Üç araştırmanın bulgularının karşılaştırılmasından sonra ortaya çıkan sonuçlara göre; bulunulan yaş aralıklarından ve sahip olunan eğitim düzeylerinden kaynaklanan farklılıklar bu eğilime daha büyük ölçüde etki etmektedir.

- Gençlerin; çeşitli yollarla bir araya gelerek kamu politikasını etkileyebileceklerine dair inançları vardır. Sosyal medya platformu da bu birlikteliği sağlayacak olan araçlardan biridir.

\footnotetext{
31Pew/Internet. (2008). "The Internet and the 2008 Election", Pew Internet \& American Life Project, Washington D.C., Erişim Tarihi:

24.03.2014,
}

http://www.pewtrusts.org/uploadedFiles/wwwpewtrustsorg/Reports/Society_and_the_Internet/PIP_2008_election.pdf 
- Gençler, sosyal medyadan edinilen bilgilere kesin doğru bilgiler olarak bakmamaktadır. Sosyal medyada yaşanan yanlış ve eksik bilgi sorununun farkında olan katılımcılar, sosyal platformlardan edindikleri bilgilerin kaynaklarını araştırmaktadır.

- Gençler İnternet erişimlerine uygulanan sınırlama ve sansürleri doğru bulmamaktadır.

- Gençler, sosyal medyayı, iletişim ve haberleşme konusunda geleneksel medyaya oranla daha çok tercih etmektedir. Ulusal ve uluslararası toplumsal olayların takibinde sosyal medya geleneksel medyaya göre daha çok kullanılmaktadır.

- ABD'de de olduğu gibi; gençler, sosyal medya üzerinden siyasi görüş bildiren paylaşımlarda bulunmayı tercih etmemektedirler.

- Wikileaks devrimi ve 17 Aralık soruşturması örneklerinde yer alan, politikacıların özel hayatının ifşasına dair kayıtların ve devlet sırrı niteliğindeki belgelerin sosyal medyada paylaşılması gençler tarafindan yanlış bulunurken, STK üyesi olan katılımcılar bu duruma daha radikal bir şekilde olumsuz bakmaktadırlar.

- Sosyal medyanın kamu düzeni açısından yararlı ya da zararlı bir oluşum olduğu konusunda halen net bir algı oluşmamıştır.

- Sosyal medyada gündeme gelen toplumsal olayların halkın kamu politikasına olan duyarlılığını yansıttığına dair genel bir kanı vardır.

- Yapılan çalışma sonucunda, kamu politikası ile sosyal medyanın; kamu politikası talepleri, taleplere bağlı olarak gerçekleşen eylemler, eylemlerin organize edilmesi, büyümesi, gündeme dönüşmesi ve uygulanan kamu politikasının sonuçlarının gözlemlenmesi konularında sıkı bir ilişki içinde oldukları ortaya çıkmıştır.

Çalışmanın ortaya koyduğu bir diğer sonuç ise üretilen kamu politikasından doğrudan ya da dolaylı olarak etkilenen kitlelerin sosyal medya aracılığı ile bu politikalara etki etme gücüne sahip olduğudur. Söz konusu gücü kullanan kamu politikası "etkilenen"leri, gelecekte de politika üretim süreçlerini kendilerine en fazla faydayı sağlayacak şekilde yönlendirmek için çabalayacaklardır. $\mathrm{Bu}$ doğrultuda, kurumları ve hükümetleri belirli bir sosyal medya politikasına sahip olmayan ülkeler, sosyal medyada halk tarafindan gündeme getirilen konuların takibinde ve kontrolünde her zaman eksik kalacaklardır. Sosyal medyaya gerektiği önemi vermeyen bu ülkeler gereken kamu politikasını yerinde ve zamanında üretemeyeceklerdir. Mevcut durumda, Türkiye de bu ülkelerden biri konumundadır.

Bu çalışmada saptanan ve yukarıda sıralanan sonuçlar, Hacettepe Üniversitesi, Siyaset Bilimi ve Kamu Yönetimi Bölümünün lisans öğrencilerinin oluşturduğu çalışma grubunu kapsamaktadır. Bu noktada bir genelleme yaparak üniversite gençliğinin tamamına veya başka kısımlarına yönelik çıkarsamalar yapmak bilimsel açıdan sağlıklı bir yaklaşım olmayacaktır. Dolayısıyla bu çalışma sonuçlarının, sadece söz konusu çalışma grubunu ve onların "Kamu Politikası ve Sosyal Medya İlişkisi” üzerindeki algılarını kapsadığını tekrar vurgulamakta yarar vardır. Bununla birlikte, mevcut bulgu ve sonuçların; mukayeselerde kullanılan Türkiye ve ABD'deki diğer iki araştırmanın bulgu ve sonuçlarıyla büyük oranda uyuşması, araştırma sonuçlarının, farklı eğitim düzeyine sahip ve farklı yaş gruplarındaki diğer toplum kesimleri üzerinde de geçerli olabileceğini düşündürmektedir. Bunun bilimsel anlamda tesbiti ise alanda yapılacak yeni çalışmalarla mümkün olacaktır, bu çerçevede "Kamu Politikası ve Sosyal Medya ilişkisi” gibi son derece yeni bir alanda Türkiye'deki ilk çalışmalardan biri olan mevcut çalışmanın, ilerideki muhtemel çalışmalara da önemli bir katkı sağlaması beklenmektedir.

Sonuç olarak, çalışma bulgularından hareketle Türkiye'de kamu politikası üretimi açısından bazı öneriler getirmek de mümkündür. Bu kapsamda, Türkiye'de, hükümetlerin ve devlet organlarının sosyal medyaya gereken önemi vererek bu konuda düzenlemeler yapmasının sosyal medya kullanımı ile değişen, çeşitlenen ve bir o kadar da karmaşıklaşan ulusal ve uluslararası siyaset ikliminde kamunun karşılıklı iletişim ve doğru bilgilenme beklentilerine daha hızlı yanıt verilebilmesi açısından oldukça faydalı sonuçlar üretmesi beklenmektedir. $\mathrm{Bu}$ 
amaçla, devlet kurumlarınca kamuya daha şeffaf, verimli ve hızlı hizmet verilebilmesi adına, sosyal medya politikaları hazırlanmalı ve süratle uygulamaya geçirilmelidir. Uygulanacak bu politikaların bağlayıcı bir niteliğe sahip olabilmesi için kanuni bir zemin hazırlanmalıdır. Hukuki düzenlemeler yapılırken, ilgili düzenlemelere kurumların vatandaşlara karşı sosyal medya üzerinden hesap verebilirliğini artıracak ve tek yönlü iletişim sorununu ortadan kaldıracak maddeler konulmalıdır. "Sosyal medyada gündem oluşturan sorunlara yetkililerce en kısa zamanda cevap verilmesi" de zorunlu kılınmalıdır. Bu şekilde hazırlanan sosyal medya politikaları; kamu yönetimindeki tek yönlü iletişim sorununa çözüm olacak, çağdaş anlamda katılımcı ve tam anlamıyla hesapverebilir bir kamu yönetiminin inşasına da önemli katkı sağlayacaktır.

\section{REFERENCES}

- Akbıyık, N. ve Öztürk, M. (2012) "Sivil Toplum ve Sosyal Medya Perspektifinde Arap Baharı ve 'Wall Street'i İşgal Et' Eylemleri", Turgut Özal Uluslararası Ekonomi ve Siyaset Kongresi -II, 19 Nisan 2012, İnönü Üniversitesi.

- C1lızoğlu, G. Y. ve Karagöz, E.Ö. (2007). Sivil Toplum Örgütlerinin Kamuoyu Oluşturma Süreci: Petrol-İş Sendikası Kampanya Analizi. Numune Matbaacılık ve Cilt San. Ltd., İstanbul.

- Çildan C., Ertemiz M., Küçük E., Tumuçin H. K. ve Albayrak D. (2012) "Sosyal Medyanın Politik Katılım ve Hareketlerdeki Rolü” Akademik Bilişim 2012 Konferansı, 1 Şubat 2012. Uşak.

- Esen, K. (2013). "Sosyal Medya Gençliği", İdarecinin Sesi Dergisi, Mayıs-Haziran: 40-45.

- Fyfe, T. and Croockall, P. (2010). Social Media and Public Sector Policy Dilemmas. Institute of Public Administration of Canada, Canada.

- GSB. (2013). Gençlik ve Sosyal Medya Araştırma Raporu. T.C Gençlik ve Spor Bakanlığı, Ankara.

- Hrdinovâ, J., Helbig, N., and Peters, C. S. (2010). Designing Social Media Policy for Government: Eight Essential Elements. The Research Foundation of State University of New York.

- Jackson, N. ve Lilleker, D. (2011). "Microblogging, Constituency Service and Impression Management: UK MPs and the Use of Twitter", Journal of Legislative Studies, 17: 86- 105.

- Jacobson, W. S. and Tufts, S. H. (2013). "To Post or Not to Post: Employee Rights and Social Media", Review of Public Personnel Administration, 33(1): 84-107.

- Kaymas, S. (2007). "İnternet ve Ulusal Kamu Politikaları: İnternet Yönetiminde Türkiye için Alternatif Öneriler", İletişim Araştırmaları, 5(2): 97-134.

- Kesen, M. (2013). "Sosyal Medya Etkisi ve Gezi Park1", İdarecinin Sesi, Mayıs:16-21.

- Kietzmann, J. H., Hermkens, K., McCarthy, L. P and Silvestre, B. S. (2011). "Social Media? Get Serious! Understanding the Functional Building Blocks of Social Media", Business Horizons, 54: 241-251.

- Kuzma, J. (2010). "Asian Government Usage of Web 2.0 Social Media", European Journal of ePractice, 9: 1-13.

- Landau, D. A. (2011). How Social Media is Changing Crisis Communication: A Historical Analysis. Master's Thesis, Fairleigh Dickinson University, NJ.

- Lee, D., Ojo, A., and Waqar, M. (2013). "Utilising Linked Social Media Data for Tracking Public Policy and Services", Workshop at Open Data on the Web, London, United Kingdom. 
- McNutt, K. (2012). Social Media \& Government 2.0.Johnson-Shoyama Graduate School of Public Policy University of Regina.

- Moran M, ve Rein M, ve Goodin R.(2006). The Oxford Handbook of Public Policy. Oxford University Press.

- Özer, B., Baştan, S. ve Ortanca, M. (2012). "Kamu Politikası Yapımı ve Kimlik-Tabanlı Siyasa Yapımı Süreçleri: Türk Kamu Yönetimine Dair Genel Değerlendirmeler", Süleyman Demirel Üniversitesi İ.İ.B.F Dergisi, 17(1): 237-263.

- Pew/Internet. (2008). "The Internet and the 2008 Election", Pew Internet \& American Life Project, Washington D.C.

- Puppis, M. (2010). Media governance: A new concept for the analysis of media policy and regulation. Communica tion, Culture \& Critique, 3, 134-149.

- İnternet Kaynakları

- IBM (2008). The Changing Face of Communication. IBM Global Services, NY, Erişim Tarihi:

08.02.2014, http://www.ibm.com/smarterplanet/global/files/au_en_us_telecom_gbe03121_usen_so cialnetwork.pdf

- Leavey, J. (2013). Social Media and Public Policy: What Is The Evidence. Alliance for Useful Evidence. $\quad$ Erişim $\quad$ Tarihi: http://www.alliance4usefulevidence.org/assets/Social-Media-and-Public-Policy.pdf 